Portland State University

PDXScholar

\title{
Understanding School Travel: How Residential Location Choice and the Built Environment Affect Trips to School
}

\author{
Yizhao Yang \\ University of Oregon \\ Marc Schlossberg \\ University of Oregon \\ Robert Parker \\ University of Oregon \\ Bethany Johnson \\ University of Oregon
}

Follow this and additional works at: https://pdxscholar.library.pdx.edu/trec_reports

Part of the Health Policy Commons, Transportation Commons, and the Urban Studies and Planning Commons

Let us know how access to this document benefits you.

\section{Recommended Citation}

Yang, Yizhao, Marc Schlossberg, Robert Parker, and Bethany Johnson. Understanding School Travel: How Residential Location Choice and the Built Environment Affect Trips to School. OTREC-RR-10-01. Portland, OR: Transportation Research and Education Center (TREC), 2010. https://doi.org/10.15760/trec.22

This Report is brought to you for free and open access. It has been accepted for inclusion in TREC Final Reports by an authorized administrator of PDXScholar. Please contact us if we can make this document more accessible: pdxscholar@pdx.edu. 


\section{SOTREC}

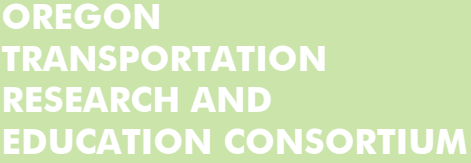

FINAL REPORT

\section{Understanding School Travel: How Location Choice and the Built Environment Affect Trips to School}

OTREC-RR-10-01

January 2010 



\title{
UNDERSTANDING SCHOOL TRAVEL: HOW LOCATION CHOICE AND THE BUILT ENVIRONMENT AFFECT TRIPS TO SCHOOL
}

\author{
Final Report
}

\author{
OTREC-RR-10-01 \\ By \\ Yizhao Yang, Ph.D. \\ Marc Schlossberg, Ph.D. \\ Robert Parker, AICP \\ Bethany Johnson, AICP \\ University of Oregon
}

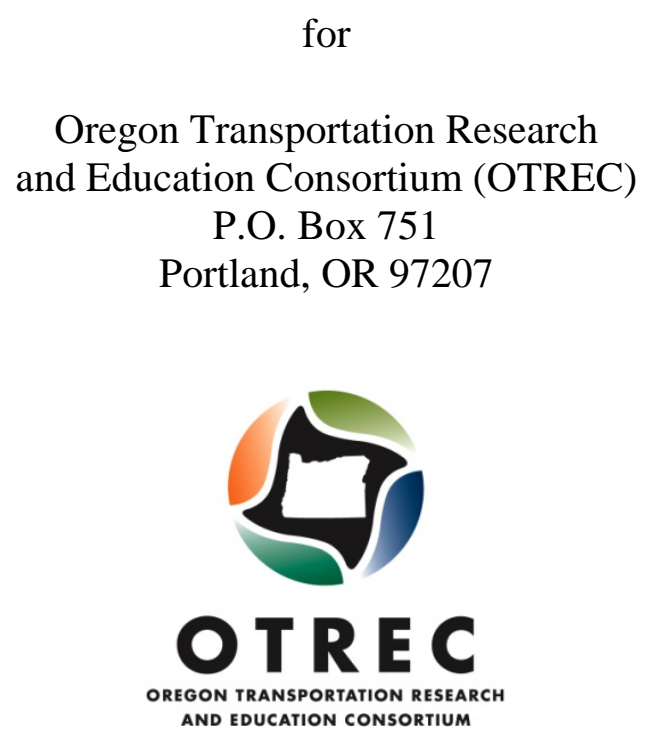

January 2010 



\section{Technical Report Documentation Page}

\section{Technical Report Documentation Page}

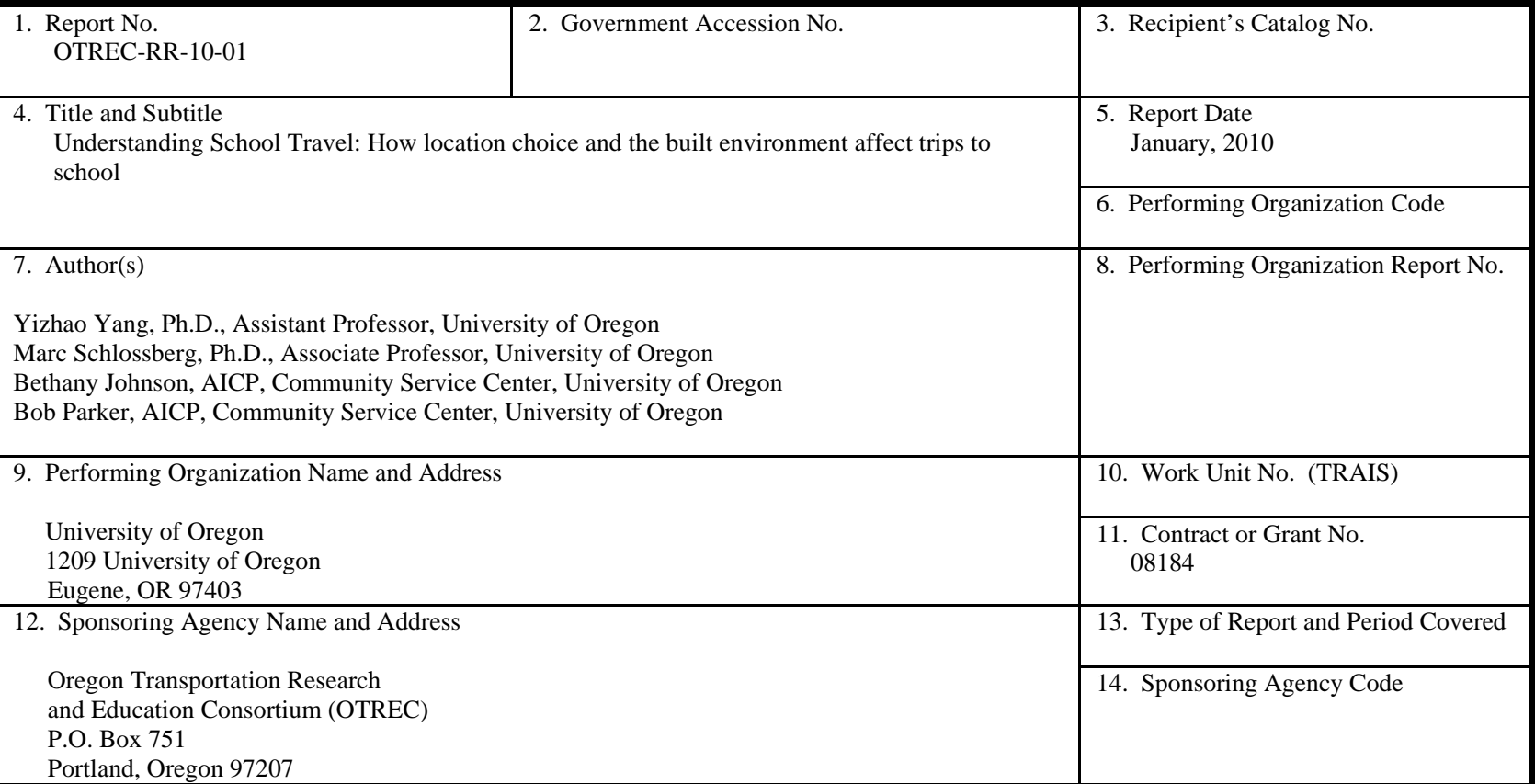

15. Supplementary Notes

\section{Abstract}

This project investigates issues related to parents' decisions about children's school transportation. This has become an important area of research due to the growing concerns that increased reliance on private automobile in school travel has led to adverse health impacts on children and negative impacts on environment. This study examines school transportation in the context of where families live and how families make decisions about school travel in the process of choosing their residence.

Using a middle-sized school district in Oregon State, we conducted a 5500-household survey and a number of interviews and focus groups. The study shows that parents considered school transportation in their residential location process; their intention to allow their children to walk or bike to school at this stage had significant impacts on later school travel behavior. While acknowledging school travel was not a priority when choosing a residential location, parents with strong preference for children walking or biking to school used residential location process consciously to live closer to school and in more walkable neighborhoods; but parents were also limited by housing opportunities around schools and in the community.

This research suggests the needs for stronger coordination between community land us planning and school planning, and stronger emphasis on changing parents' attitudes toward children walking or biking to school in programs around safe routes to schools.

17. Key Words

Active School Commuting, healthy community, school travel
18. Distribution Statement

No restrictions. Copies available from OTREC: www.otrec.us
19. Security Classification (of this report)

Unclassified
20. Security Classification (of this page)

Unclassified

\section{No. of Pages}

59 


\section{Acknowledgement}

We'd like to thank the Oregon Transportation Research and Education Consortium for funding this project. We also would like to thank students who participated in this research project via the Community Planning Workshop. Under the supervision of Bethany Johnson, graduate students Nick Fleury, Jenny Kuykendoll, Sara Schooley and Amanda West conducted all interviews and focus-group research that collected rich, qualitative information. These students also helped with survey instrument development. We would like to thank the 4J School District for providing us with a student-address database.

\section{Disclaimer}

The contents of this report reflect the views of the authors, who are solely responsible for the facts and the accuracy of the material and information presented herein. This document is disseminated under the sponsorship of OTREC and the U.S. Department of Transportation University Transportation Centers Program in the interest of information exchange. The U.S. government assumes no liability for the contents or use thereof. The contents do not necessarily reflect the official views of OTREC or the U.S. government. This report does not constitute a standard, specification, or regulation. 


\section{TABLE OF CONTENTS}

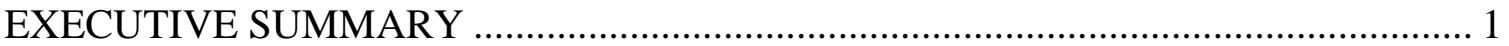

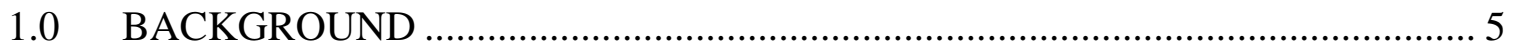

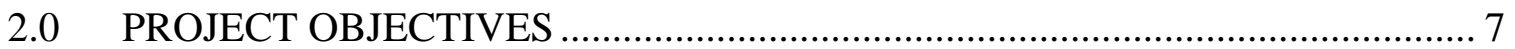

3.0 LITERATURE REVIEW ......................................................................... 9

3.1 Association between Residential-Location Choice and Travel Behavior in Travel-

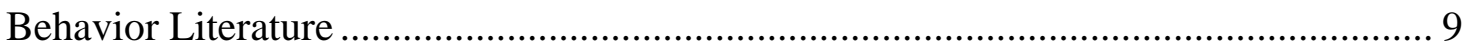

3.2 Factors Affecting Active School Commuting in School-Travel Literature............ 10

3.3 From Travel Preference and Intention to Residential-Location Choice: The

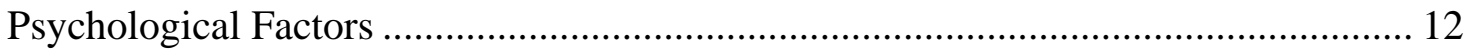

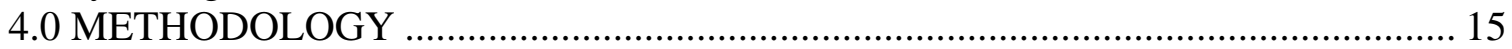

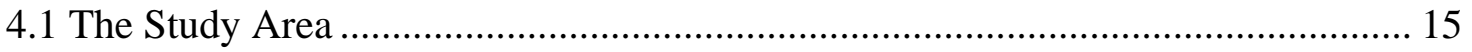

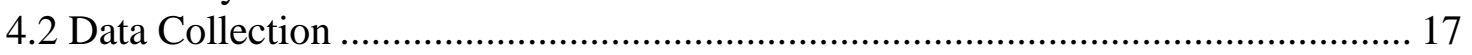

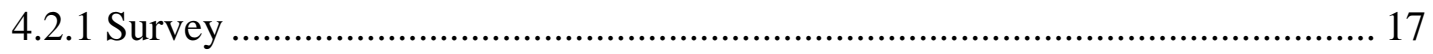

4.2.2 Interviews and focus groups ...................................................................... 17

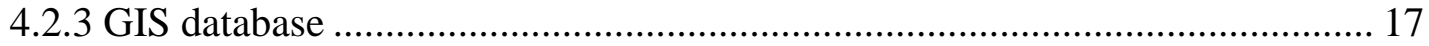

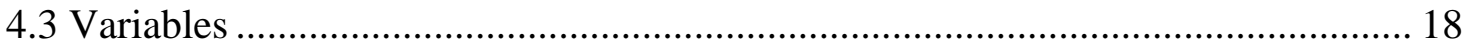

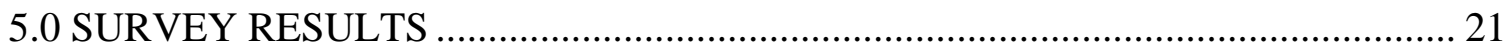

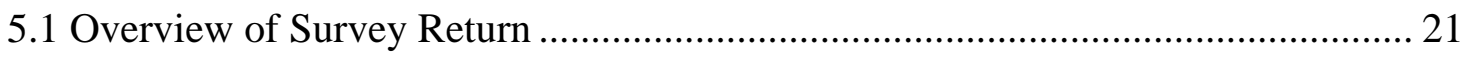

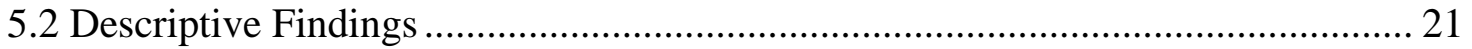

5.2.1 School-Travel Patterns.............................................................................. 21

5.2.2 Reasons behind using active school travel and driving to school..................... 22

5.2.3 Attitude toward Active School Commuting and Driving ................................. 24

5.2.4 Consideration of School Travel in Residential-Location Choice ..................... 25

5.3 ASC Preference, residential-location choice, and school-travel behavior............... 26

5.3.1 Preference for Active School Commuting and Residential-Location Criteria 26

5.3.2 Using ASC Preference to Predict Home-School Distance ................................ 28

5.3.3 Using ASC consideration during location process to predict ASC behavior .. 29

6.0 RESULTS FROM INTERVIEWS \& FOCUS GROUPS .......................................... 31

6.1 Findings from Parent Focus Groups …………………......................................... 31

6.1.1 Accessibility to school in Residential-location choice ..................................... 31

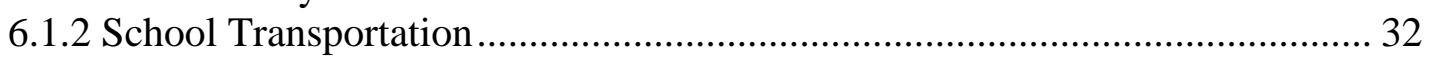

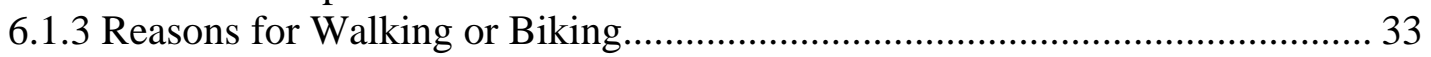

6.1.4 Reasons for Driving ...................................................................................... 34

6.2. Findings from Community Interviews \& Focus Group ............................................ 34

6.2.1 Community Land-Use Planning and Residential Development ....................... 34

6.2.2 School Planning and Policies........................................................................... 35

6.2.3 Programs Promoting Active School Commuting ………………………......... 37

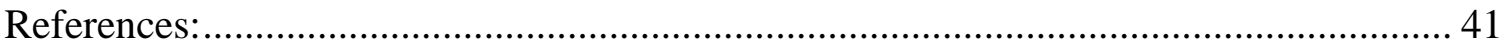

Appendix A: Survey Instrument .................................................................................... 49

Appendix B: Survey Questions for Measuring Important Variables .................................. 57

Appendix C: Descriptive Statistics for Major Variables ..................................................... 59 


\section{LIST OF TABLES AND FIGURES}

\section{Tables}

Table 5-1: Comparison of Important Characteristics between Survey Respondents and

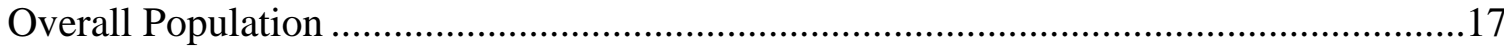

Table 5-2: Correlations between ASC Preference and Parent Attitudes ...........................20

Table 5-3: Mean Comparison of Attitude and Preference Scores among Population

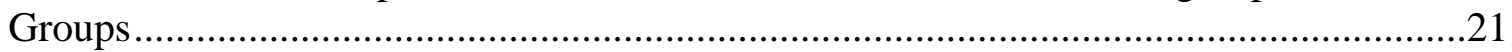

Table 5-4: Ranking of importance level among 21 factors in location decision ...............24

Table 5-5: Output from OLS Regressions .................................................................24

Table 5-6: Logistic regression: predicting children walking/biking to school at least three

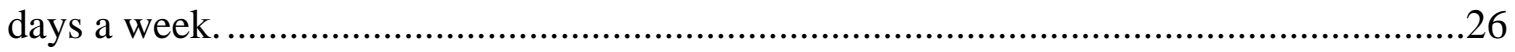

Table 6-1: Parents' preferred housing priority ......................................................27

\section{Figures}

Figure 3-1: A conceptual framework connecting preference, location choice and behavior

Figure 4-1: Location of Schools Included in Survey ....

Figure 5-1: Statistics of School-Transportation Mode during a Typical Week ................18

Figure 5-2: Top Five Most Important Reasons for not Using ASC................................19

Figure 5-3: Top Five Most Important Reasons for Using ASC ......................................19

Figure 5-4: Average importance scores for 21 factors considered in residential-location

choice 


\section{EXECUTIVE SUMMARY}

This project looks at the issues related to parents' decisions about children's school transportation, and examines school transportation in the context of where families live and how families make decisions about school travel in the process of choosing their residence.

Specifically, this study tries to answer the following three questions:

- Is children's school commuting explicitly considered when households decide where to live?

- To what degree does parents’ preference for active school commuting (ASC) affect their decision-making process for residential location?

- To what degree does parents' consideration of using ASC during the housinglocation selection process affect later school-travel behavior?

This project employed both quantitative and qualitative methods to answer these questions. The 4J School District in Lane County, OR, was used as the study area for conducting surveys and interviews. Discounting 126 non-deliverables, 1,197 surveys were returned at a 21 percent response rate. A comparison of several socio-demographic and housing characteristics of the sample to those of the population suggests that the survey response is reasonably representative of all households of elementary school students in the school district.

Four focus groups were conducted involving three parent-only groups and one made up of professionals (city planners, real estate agents and school district administrators). In addition, 13 key informants knowledgeable about schools, residential-location decisions and transportation were interviewed. Information collected through these interviews provided supplementary information and insights into the analytical results based on survey data.

The main findings from the survey are summarized below:

- There is significant discrepancy in the level of preference for ASC and the actual school-travel behavior.

Overall, about 15.4 percent of parents surveyed reported that their child walks or bikes to school (with or without an adult) at least three days a week, a similar frequency (14.4\%) for students who walk or bike from school. On the contrary, about 70 percent of parents agreed $(28.7 \%)$ or strongly agreed $(42.4 \%)$ with the statement that "if possible, I prefer my child walk or bike to school."

- The majority of parents in the survey considered school transportation in their residential-location process, and their intention to use ASC at this stage had significant impacts on their later school-travel behavior.

Overall, about 78 percent of parents thought about school transportation when they chose their current residence, which includes 60 percent of parents who had just one type of travel means in mind (e.g., walking/biking, car, school bus) and 18 percent of parents who had more than one type of transportation means in 
mind when they chose their current residence. For respondents who considered school travel, walking or biking was the most frequently mentioned travel means (44\%), followed by private automobile (37\%) and school bus (36\%). The odds of a child walking or biking to school at least three days a week increases by a factor of 5.42(times) if his or her parents thought about using ASC when moving to their current residence.

- The effects of the built environment on the use of ASC come from two sources: (1) School-environment characteristics have strong impacts on parents' housing choice with respect to ASC; (2) School-environment characteristics have relatively weak (or very limited) influences over the use of ASC.

The land-use mix and residential density around schools had strong impacts on parents' housing-location characteristics in terms of home-school distance and neighborhood walkability. These school-environment characteristics, however, did not seem to impact the use of ASC. Only street-network characteristics around schools (i.e., stronger road connectivity) showed impacts on the use of ASC.

- There are distinctive effects from environmental characteristics such as homeschool distance, neighborhood walkability, and parental safety concerns on the use of ASC.

Longer home-school distance and poorer neighborhood walkability was associated with lower odds of using ASC. Home-school distance's influence on ASC was stronger and statistically more significant than that of neighborhood walkability.

The main findings from the interviews and focus groups are summarized below:

- Parents reported that there were very limited housing options in the community. School travel was less of a priority in location choice compared to housing affordability, neighborhood appearance, and recreational opportunities.

School travel was not a priority when choosing a residential location. As Eugene is relatively small, parents felt the distance to a school was less important than it may be in a larger city or one with higher traffic volumes. Affordability, impression of the neighborhood and recreational options appeared to be important factors when choosing a residence.

- There is little coordination among community land-use planning and school planning.

The current plan in Eugene stresses concentrated redevelopment and infill development. However, neighborhoods are prioritized for development based on their location to commercial services. School location plays little role in higher density development.

- Some school policies had adverse impacts on the use of ASC.

School-siting criteria encouraged development of larger schools at more urban fringe locations. The use of school-choice policy without busing accommodation led to greater use of private automobiles in school transportation. 
The findings in this study lend support to the contention that choice in residential location provides a mechanism by which ASC preference exerts influence on later behavioral patterns. While many environmental characteristics (e.g., home-school distance, safety, walkability) still play a role in affecting parents' decisions, consideration of using ASC at an early stage greatly influences later travel behavior. 


\subsection{BACKGROUND}

The past several decades have witnessed a rapid increase in parents driving children to school. According to the 2001 National Household Travel Survey, about 65 percent of all children arrive at school in private automobiles, compared to 18 percent in 1969 (Bureau of Transportation Statistics, 2003; EPA, 2003). Increased reliance on private automobiles in school travel has led to concerns over both the adverse health impacts on children (Strauss and Pollack, 2001; O’Brian, 2003; Sallis and Owen, 1999) and the negative impacts on the environment (EPA, 2003). Research has shown that school trips by private vehicles are oftentimes of short distance ( $<2$ miles) and are concentrated in morning and afternoon traffic peak hours around schools (Ewing et al., 2004). This type of travel leads to lower fuel efficiency and causes more serious pollution. School trips now account for 10 percent of all short trips. In some communities, close to 30 percent of morning peakhour traffic is for school-related trips (Dubay, 2003).

To increase the rate of children walking or biking to school is now at the center of many federal, state and local programs and policies. The Centers for Disease Control and Prevention's "Kids Walk-to-School" campaign and the Safe Routes to School programs in a number of states are examples. A primary focus of these public efforts has been on using environmental-based interventions to change travel behavior. These involve locating schools close to residential districts and providing a supportive physical infrastructure for pedestrians and bicyclists.

The success of public interventions to influence a shift in school travel from auto-based to walking and biking will largely depend on parents' response, as they are the primary decision-makers for children's travel. Current understanding of parents' decision-making process, however, is limited. Most existing studies have treated parents' decisions as a reaction to environmental conditions. In other words, parents make judgments on the walkability of the existing environment between home and school, and then make decisions about whether to allow their children to walk or bike to school (McMillan, 2003 \& 2005). In reality, however, parents' decisions about school transportation may start while choosing residential location (Black et al., 2001; Ewing et al., 2004). Parents who intend to have their children walk to school may deliberately choose a residence close to a school and in an environment conducive to walking and biking, whereas parents lacking such intentions may ignore the home-school distance or easily trade off school accessibility with other family needs, such as affordable housing, a good neighborhood, and good access to employment.

Admittedly, few families would choose to live far from their children's school. As surveys in residential-location choice show, proximity to school is the fifth most frequently cited reason for choosing a family's residence (Rossi, 1980; Kestens, 2004). However, it may be easier in some communities for families with school-age children to live close to school than in others. As data from the American Housing Survey indicate, in Orange County, CA, more than two-thirds of children reside within a one-mile distance from their elementary schools, whereas in Charlotte, N.C., more than two-thirds of children live beyond a one-mile distance (Yang, 2007). The general home-school spatial relationship in a community may be strongly influenced by school locations in relation to both housing opportunities and land-use distributions. From the school-travel 
perspective, making walking and biking to school a reasonable option for families with children requires not only schools being close to residential neighborhoods but also that housing opportunities and land-use mix within school catchment areas are able to accommodate the needs of families with school-age children.

Surveys have consistently revealed that long distance between home and school is the primary barrier to active school transportation (CDC, 2004; EPA 2003). Studies have also shown that home-school distance is the strongest predictor for walking or biking to school (Black et al., 2001; McMillan, 2005; Schlossberg et al., 2006). Several scholars have pointed to the need to consider school travel as an integral part of residentiallocation choice (Black et al., 2001; Ewing et al., 2005). Very little has been known, however, about how families make their residential-location choice as it relates to school travel. 


\subsection{PROJECT OBJECTIVES}

The primary goal of this project is to examine school transportation in the context of where families live and how families make decisions about school travel in the process of choosing their residence. Acknowledging the impacts that residential environment characteristics (e.g., the built environment) have on school-travel mode choice, our project aims to address the self-selection issue that currently has been ignored in schooltravel research.

Specifically, this project investigates the role played by parent attitudes and/or preference in connecting residential location choices and school-travel behavioral outcome. This project studies (1) whether and how parents consciously use residential location to obtain the kind of environments congruent with their school-travel preference, and (2) how decisions made on school travel during the residential-location process may later affect actual school-travel patterns. In other words, it is recognized in this study that the residential-location decision may well be a stage at which choice regarding school-travel mode is considered or even determined.

This project tries to answer the following three questions:

- Is children's school commuting explicitly considered when households decide where to live?

- To what degree does parents’ preference for active school commuting (ASC) affect their decision-making process for residential location?

- To what degree does parents’ consideration of using ASC during the housinglocation selection process affect later school-travel behavior?

This project also assesses the degree to which home-school proximity, the walkability of the neighborhood around schools, and household characteristics affect the use of ASC. While most existing school-travel research focuses on the direct influence environmental factors have on ASC, this project attempts to expand the understanding of the role the built environment plays in affecting ASC. This study aims to highlight the fact that many environmental characteristics affect families' ability to live closer to school and in more walkable neighborhoods in the first place.

This project tries to answer two additional questions:

- What association is there between the built environment, family background and parent attitudes in choosing school-travel modes?

- What is the overall impact of the built environment on school travel, including the direct impact on walkability and the indirect impact on residential location choice? 


\subsection{LITERATURE REVIEW}

\subsection{Association between Residential-Location Choice and Travel Behavior in Travel- Behavior Literature}

Recent research on travel behavior has drawn attention to the association between people's travel behavior and their residential-location types and characteristics. Studies have shown that people residing in places with higher densities, greater land-use mix, better street connections, and/or public transportation accessibility had lower levels of auto trips and higher frequencies of using other types of travel means, such as public transit, walking and biking (Cereveo and Gorham, 1995; Friedman et al., 1992, Newman and Kentworthy, 1999; Rutherford et al., 1996).

Despite the growing evidence, many scholars have been cautious in drawing the conclusion that differences in travel behavior are the consequence of residential-location choices (e.g., Crane, 2000; Handy et al., 2006). It has been recognized that people with strong preference for a certain travel mode may self-select into places that can best support the use of their preferred travel modes (Choocharukul et al., 2008). Thus, the observed environment-travel behavior association may merely be attributed to the fact that residential-location choice serves to accommodate behavioral predisposition rather than prompt the observed travel behavior.

Indeed, some studies show that residential location exhibits little impacts on travel-mode choice once the correlation between attitude/lifestyle and location choice has been taken into account (see, for example, Bagley and Mokhtarian, 2002). Others suggest that residential location still affects travel behavior even after controlling for travel preference and self-selection, albeit that the effects are, at most, modest (Cao et al., 2006; Khattak and Rodriguez, 2005; Krizek, 2000; Nasae, 2005; Schwanen and Mokhtarian, 2005).

Current consensus in the research field appears to be that the causal relationship between residential location and travel behavior could be both ways. In other words, the type and characteristics of residential location may cause more frequent use of certain travel modes and travel-behavioral patterns; on the other hand, people's travel-behavior intentions or preference may lead to the selection of certain residential environment types.

Much of the exiting research has focused on studying the first relationship -- residential location influencing travel behavior. Treating the possibility of self-selection as mainly a nuisance problem, researchers have experimented with increasingly sophisticated methods and instruments in the identification of the "true" relationship between the built environment and travel behavior (Bagley and Mokhtarian, 2002; Bhat and Guo, 2007; Greenwald and Boarnet, 2002; Kitamura et al., 1997; also see a summary by Mokhtarian and Cao, 2008).

What has been understudied is the latter relationship concerning how people's travel intention or preference may significantly affect residential-location choice (Choocharukul et al., 2008). A better understanding of this issue not only leads to a more accurate assessment of the real impacts environment has on travel behavior, but also improves travel research in several ways. 
First, the consideration of such psychological constructs as preference and attitudes greatly expands the meaning associated with travel behavior beyond simply getting from one point to another (i.e., derived demand). A study by Schwanen and Mokhtarian (2007), for example, revealed that people opt for higher-density living in part because they are concerned about the environment and want to reduce their auto travel, whereas lower-density living is chosen in part because it is better geared to fast, flexible, and comfortable auto travel and makes it easier to display cars as status symbols. Such findings indicate the need for greater education to improve people's environmental and health awareness as part of the policy solution to auto dependence.

Second, with the acknowledgment that people do actively seek certain locations to enable desired transportation options, research in this area highlights the fact that travel-mode choice is highly conditioned upon environmental factors. It also leads to the question about the degree to which the current supply of land-use configuration may have suppressed desired transportation behavior. Several studies have noted the dissonance between the types of neighborhood people prefer and where they actually live (Schwanen and Mokhtarian, 2005) and the likely insufficiency in the supply of environments that supports non-auto travel (Levine and Inam, 2004). These findings illustrate that the benefits of modifying an environment relies not only on "inducing” more desirable travel behavior but also “enabling” existing travel preference.

While recent travel studies have started filling the gap in the understanding of selfselection, school-travel literature has yet to address this issue, although some researchers have pointed out the likely dependence of home-school distance and neighborhood walkability on parents' preference for and attitude toward certain travel means (see, e.g., Ewing et al. 2004). There exists little school-travel research that testifies to the relationship among parental attitude, housing location, and school travel.

\subsection{Factors Affecting Active School Commuting in School-Travel Literature}

Existing school-travel literature has identified a number of factors that impact travel choice. These factors can be grouped into (1) the built environment, (2) social environment, and (3) school characteristics and family/household characteristics.

For the built environment, objectively measured or subjectively perceived, two aspects have so far received the most attention in existing literature: home-school distance and neighborhood walkability.

Studies have consistently revealed that long distance between a student's residence and his or her school is the primary barrier to walking or biking to school, and children are more likely to walk if they live less than a mile from school (EPA, 2003; Black et al., 2001; Dellinger, 2002; McMillan, 2005; Schlossberg et al., 2006; Wen et al., 2008, McDonald, 2006 \& 2007).

Studies also show that walkability characteristics of the environment close to school correlate with the rate of children walking or biking to school (Transportation Research Record, 2001; Kerr et al., 2006; Schlossberg et al., 2006), although their effects were often found smaller than that of the home-school distance (Steiner et al, 2006). Urbanform elements that affect walkability include such measures as housing density, sidewalk 
connectivity, street connectivity, road type/function, and street tree coverage (Boarnet et al., 2005; Ewing et al., 2004; Schlossberg et al., 2006).

Social conditions that affect school-travel behavior involve various social qualities that may impact parents' decision about letting their children get engaged in physical activities within their neighborhoods or communities (Molnar et al., 2004; McDonald, 2007).

Mostly measured with parents' own perception and assessment, these social conditions include safety or security concerns, social interaction/relationship, and social control/social support (McMillan, 2003; McDonald, 2007). Studies have shown that perceived crime danger is a major barrier to children walking and biking to school (Dellinger, 2002; Kerr et al., 2006; Schlossberg et al., 2006) and stronger social cohesion/control increased the likelihood of students walking to school, particularly for those living within one mile of school (McDonald, 2007).

A number of proxy measures of neighborhood social conditions, such as indicators of neighborhood socioeconomic status (e.g., neighborhood household income levels, poverty levels, and occupational makeup), have also been found to correlate with the rate of children walking or biking to school (Ewing et al., 2004; McDonald, 2007).

School characteristics also received attention in recent studies. A recent study showed that the types of schools (magnet schools vs. neighborhood schools) had effects on the likelihood of a child walking or biking to school (Willson et al., 2007; Willson, 2008). Ewing et al. (2004) considered the potential effects of enrollment size on school-travel behavior, although the findings were inconclusive.

Some family/household characteristics, such as the number of cars owned, the number of licensed drivers and higher household income, have been found to be associated with a greater likelihood of automobile use in school trips (Ewing et al., 2004; Wen et al., 2008). Children's own characteristics (e.g., physiological adequacy) also play a role, with younger children and girls showing a lower likelihood of walking or biking to school (Wen et al., 2008).

Parental behavior and attitudes, a particular aspect of the family/household characteristics, has received some attention in recent studies of travel behavior. Black et al. (2001) examined the effects of parents' attitudes toward car use for school trips. Using a series of attitudinal statements, they identified three value orientations underlying parents' caruse attitudes: environmental awareness, car-centeredness, and individual responsibility. Their analysis showed that these attitudinal variables had explanatory power after controlling for the environmental conditions. Particularly, among the three factors, carcenteredness exhibited the strongest impacts on school-travel behavior. McMillan (2007) also reported that caregivers' belief in the convenience of driving and the value of interacting socially with other children during the journey impacts children's (un)likelihood of walking or biking to school.

It is logical to assume that parents with a preference for certain school-travel modes are likely to decide their residential location in line with their preference or attitude. While there have been several studies that take parents' attitude and preference into 
consideration, none of them has made an explicit connection of those variables to the residential-location process (Black et al., 2001; McMillan, 2007; Wen et al., 2008).

\subsection{From Travel Preference and Intention to Residential-Location Choice: The Psychological Factors}

Overall, there is an insufficient amount of work addressing the connection between school travel and residential-location choice. This can be attributed to the lack of attention paid to the attitudinal factor in school-travel research. Attitudinal variables are commonly omitted from studies. Even in studies including travel attitude or preference in their analysis, the purpose was often to control for the potential self-selection problem in order to identify the "true" causality underlying the environment-travel-behavior relationship (see, e.g., Bhat and Guo, 2005; Mokhtarian and Cao, 2008).

Two reasons may account for such a gap:

1. The lack of an integrating conceptual framework. The utility-maximization model grounded in consumer-choice theory treats modal choice as a process of comparing utilities associated with various possible travel modes. Travel is recognized as a derived demand (trips are made for a purpose), and attributes of travel modes, such as cost, convenience and comfort, become the primary determinants. An activity-based model or approach, on the other hand, recognizes school travel as part of a composite of overall household travel patterns and highlights family-activity patterns, environmental characteristics around destinations, etc., in travelers' decision-making.

2. An additional reason may be due to researchers' unawareness of the strength of such factors' impacts on travel behavior and/or the perception that attitudinal factors are not amenable to public policies. The difficulty in operationalizing those psychological concepts and data unavailability also contribute to the problem.

It should be noted that the psychological variables discussed here (preference, attitude, intention, etc.) are distinctive from the environmental perception and/or assessment variables included in many school studies (e.g., perceived safety concerns, walkability, and/or traffic condition). The former is a function of one's positive or negative evaluation of performing a particular behavior based on his or her knowledge and experience (Ajzen and Fishbein, 1975), whereas the latter pertains to subjective recognition and interpretation of sensory stimuli chiefly derived from the physical or social environments (Eyles, 1990).

Attitude and intention have been considered as the most important determinants of human behavior in social psychology (Ajzen and Fishbien, 1975; Ajzen, 2001 \& 2002). Both terms of have been used loosely in travel behavior research without a precise definition. Before moving into a discussion of a conceptual framework that helps integrate residential-location choice and travel-mode choice, it is necessary to clearly define the concepts and constructs that play predominant roles in the theoretic logic.

It also is necessary to clarify that the major players most appropriately applicable in this analysis are adults (parents and guardians) who decide school-travel behavior for young children (elementary students). Since decisions about school travel for this age of 
children are made, by and large, by the parents /guardians, this allows us to treat school travel as a complex and rational social behavior that can be understood and explained by studying parents' attitudes, beliefs, and perceptions toward a number of factors ranging from personal and social to environmental (McMillan, 2005).

In social psychology, attitude toward a behavior (i.e., behavioral attitude) refers to "a person's positive or negative evaluation of performing the behavior (Ajzen and Fishbien, 1980:6)." Attitude can be directly measured by asking a person how well he or she is in favor of or against performing the behavior, but more often it is inferred from people's behavioral beliefs about the likely consequences associated with performing the behavior (Ajzen and Fishbien, 1980). In other words, attitude formation is personal in nature, rooted in a person's individual experience, knowledge, and perception.

Intention, on the other hand, is an indication of an individual's readiness to perform a given behavior (Ajzen, 2002). Researchers have suggested that, when respondents are asked to indicate their intentions in a hypothetic situation with relaxed constraints from external conditions, stated intention is similar to stated behavioral preference (Fujii and Garling, 2003). Intention or stated preference can be considered as dictated by a person's general desire to act but also constrained by a person's perceived environmental support/control, in other words, his or her realistic assessment of whether performance of the behavior is possible. The former (general desire) is obviously influenced by a person's behavioral attitude, and the latter (assessment of external constraints) is a function of many external condition/factors.

Compared with attitude, intention is generally a better and more immediate predictor as it captures the influence of external conditions (Ajzen and Fishbien, 1980). Frequent inconsistency between intention and behavior has been observed, however, particularly when performing the behavior is subject to the influence of other psychological factors such as perceived social pressure and personal moral obligation. The intention-behavior inconsistency may also increase as a result of unrealism in one's assessment of external constraints (Ajzen, 1985) and the sensitivity with which one reacts to changes in environmental conditions.

A conceptual framework guiding the research design is developed based on theories in social psychology (see Figure 3-1), which leads to three hypotheses: (1) people's preference for ASC is formed on the basis of their attitude, (2) people's preference for ASC affects the decision-making process in their housing-location choice, and leads to a residential environment that is more conducive to ASC (i.e., closer to school and better walkability), and (3) along with environmental conditions, people's intention to or consideration of using ASC during their residential-location choice impacts patterns of using ASC.

Compared to the activity-based model underlying many school-travel studies explicitly or implicitly (e.g., McMillan, Schlossberg), the conceptual framework adopted in this study assigns a more prominent role to personal motivation. This helps address the selfselection issue and allows for a more accurate estimate of the impacts of environmental factors on behavior. Compared to transportation modeling that treats travel as "derived demand” and relies on consumer-choice theory (e.g., Ewing, 2004; McDonald, 2007c), this approach expands consideration of utilities or dis-utilities associated with school 
commuting. We include in people's decision-making process beliefs about potential behavioral outcomes (e.g., health benefits, environmental impacts, etc) beyond the generally considered travel attributes (e.g., travel time, distance, etc).

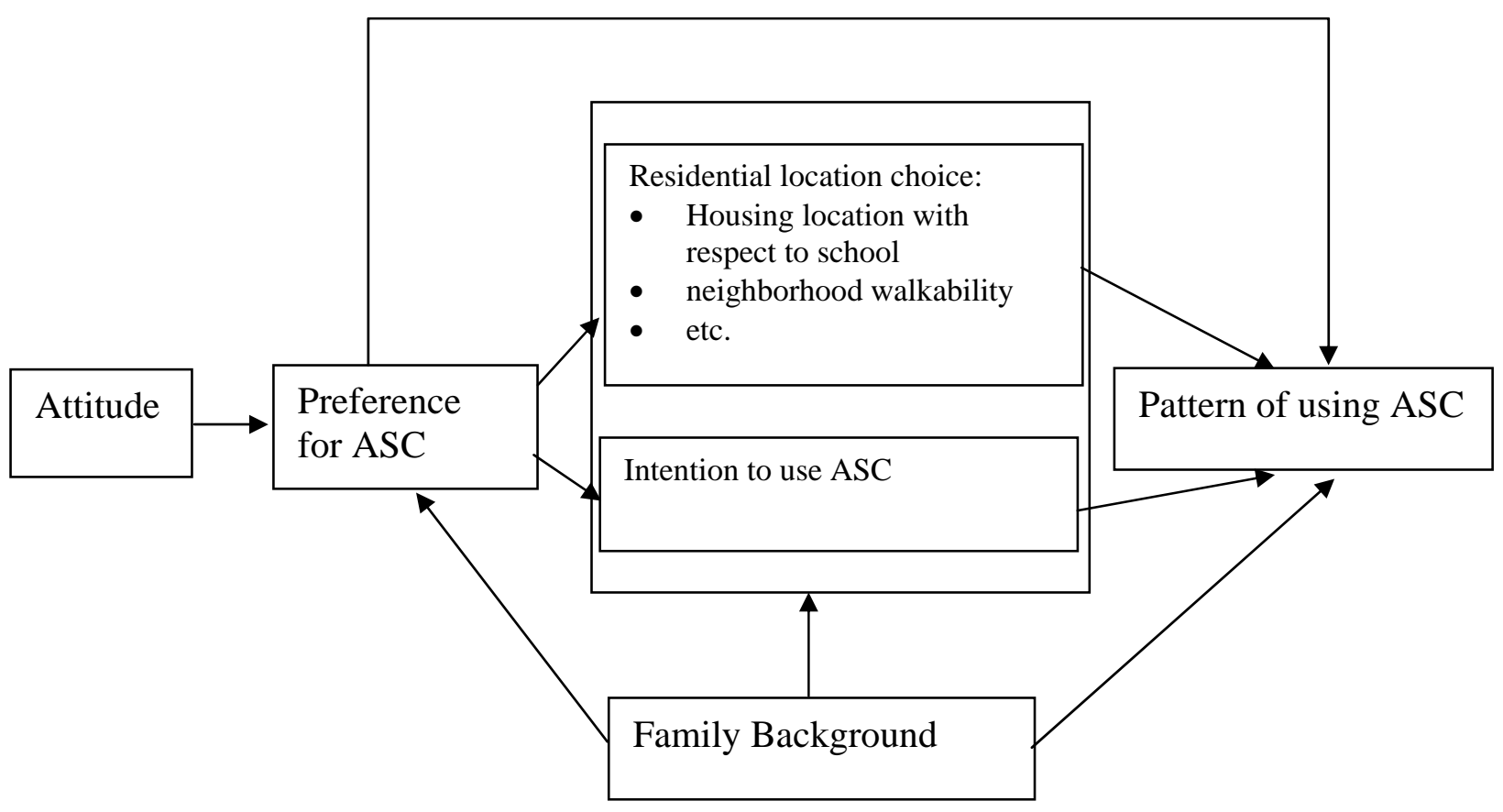

Figure 3-1: A conceptual framework connecting preference, location choice and behavior 


\subsection{METHODOLOGY}

To gain a better understanding of the interconnection between residential-location choice and school-travel choice, this project conducted both quantitative and qualitative analysis using data and information collected through a survey and several focus groups.

This study is both exploratory and explanatory. On one hand, it attempts to identify the mechanism by which school-travel consideration is integrated in residential-location choice. To do so, it studies potential factors assessed by people in housing-location choice and compare their relative importance in determining residential location. On the other hand, it aims to identify the degree to which behavioral preference affects people's housing location with respect to school, and the degree to which consideration of ASC during housing choice affects later behavior patterns.

\subsection{The Study Area}

The study area is the 4J School District in Lane County, OR. This school district spans 155 square miles in the southern Willamette Valley, mainly serving the city of Eugene. Twenty-six elementary schools in this district enrolled approximately 6,000 students during the 2007-2008 academic year. Among these schools, 18 are traditional elementary schools (i.e., neighborhood schools) and eight are so-called "alternative schools" with certain special programs (e.g., foreign language education, art, or music curriculum). See Figure 4-1 for school locations.

Each of the neighborhood school has a service zone that defines the neighborhood from which a school receives its student enrollment. A neighborhood school can accept students outside its service zone if space is available and the students choose to come to the school via the school-choice program. The alternative schools do not have defined service zones and enroll students via a lottery-based, district-wide enrollment policy. In this study, the type of school a student attends is differentiated as either a neighborhood school or a choice school (an alternative school or a neighborhood school a student attends via the school choice program).

The target population in this study is parents of young children attending elementary schools. As indicated earlier, the school-travel decision for children at these young ages is made by their parents /guardians, thus more reflective of parents' attitudes and intention (see McMillan, 2005). This population group also has a high residentialmobility rate, and their residential-location process is likely to involve simultaneous considerations of purchasing a house, deciding on schools, and evaluating travel options.

While it may be unique and thus limit the ability to generalize the research outcome, this study area does possess some characteristics that are important for revealing the effects of attitudinal factors on school-travel behavior. Eugene is a place known for its support of outdoor activities and well-equipped infrastructure for biking and walking. The extent to which physical activity is normative within a community may influence walking or biking to school. The use of the alternative travel mode (automobile) is likely to be less habitual in Eugene than in many other places in this country. All these characteristics could allow for identification of a more distinctive relationship between 
attitudes/preference and residential-location choice and between attitudes/preference and behavior.

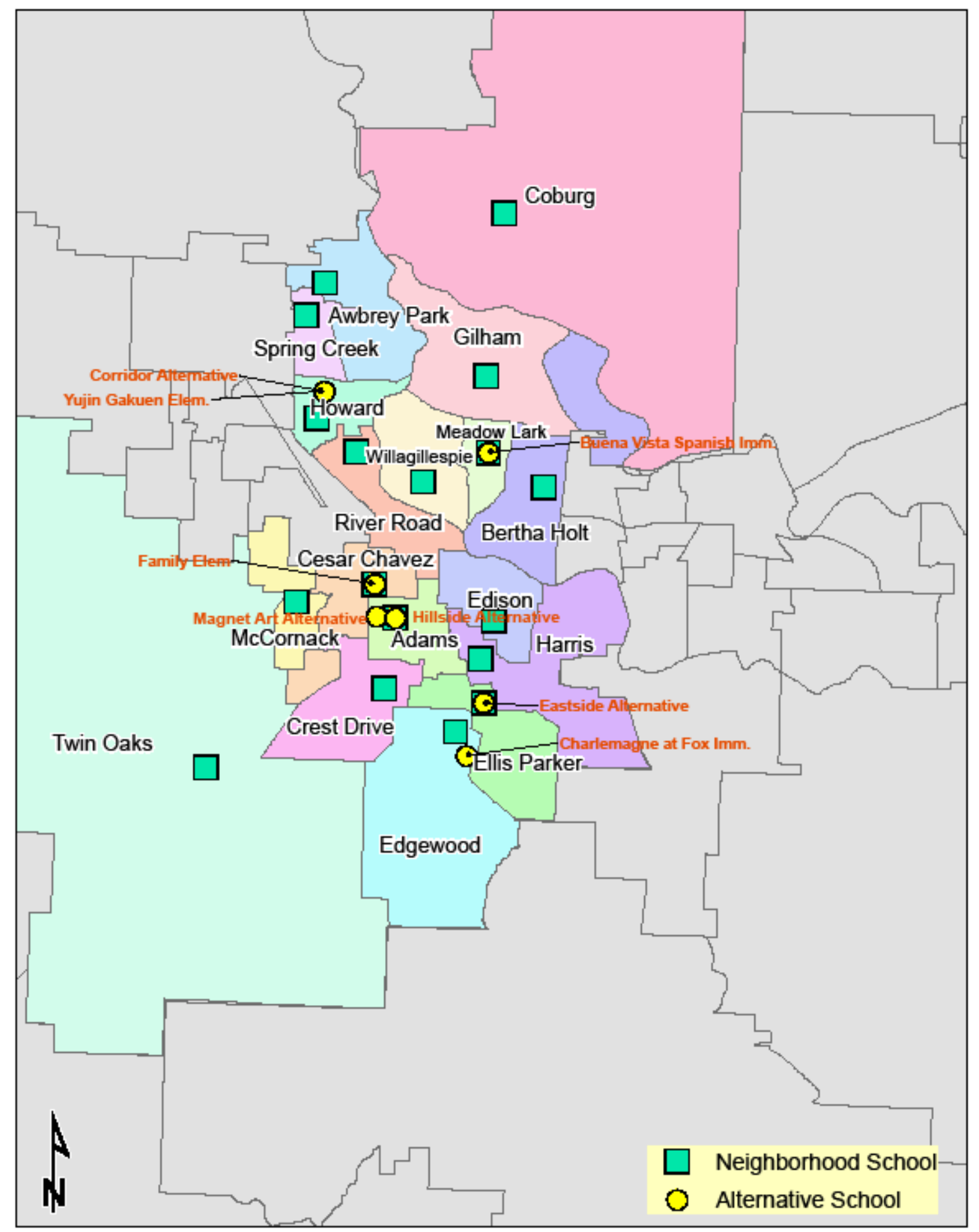

Figure 4-1: Location of Schools Included in Survey 


\subsection{Data Collection}

\subsubsection{Survey}

A school-travel survey was mailed in the spring of 2008 to all households $(5,700)$ with children attending elementary schools (K through 5) in the 4J School District and residing within the city boundary of Eugene.

The survey included questions about children's school-travel behavior similar to those used in other studies (e.g., Schlossberg et al., 2006). It also included questions regarding parents' school-travel preference, perceptions of environmental conditions, and sociodemographic background. There were also questions pertaining to criteria parents used in their housing decision and consideration of school travel during the residential-location process. Parents were instructed to fill out the survey for their eldest child if more than one child in the household attended elementary school (see Attachment A for the survey letter).

\subsubsection{Interviews and focus groups}

To supplement the survey study, rich, qualitative information about parents' decisionmaking process for their residential-location choice and children's school trips also was collected via focus groups and interviews.

Three parent focus groups were conducted to collect additional information related to parents' school-travel habits and their consideration of school travel in residentiallocation decisions. Parents were recruited from those who indicated their willingness to participate in a focus group in the survey, and an average of 10 parents came to the focus group. Parent focus groups were conducted by graduate students participating in a course titled, "Community Planning Workshop."

Another focus group was held among professionals (local planners, real estate agents, people from the school district, etc) to discuss issues about transportation, school siting, and community housing options in depth. This group included one land-use planner; one growth-management planner; two transportation planners; one representative from the Smart Ways to School Program and one from the Safe Routes to School program; four individuals involved in real estate; one school district administrator; one school facilities contact; and one elementary school principal. This study also conducted interviews with 13 key informants knowledgeable about schools, residential location decisions and transportation, including real estate professionals, planners, school administrators, and community members.

\subsubsection{GIS database}

A GIS database was created to map out family locations, measure home-school distances, and develop urban form indicators (e.g., land-use mix, street patterns, and housing mix) around school sites. 


\subsection{Variables}

Active School Commuting Variables

Survey respondents answered questions about the number of days that they used different school travel means in a typical school week. A family is considered as using active school travel as the primary transportation means if its child walks or bikes to (or from) school at least three days a week. This study focuses on the to-school travel, and used the number of days students walked or biked to school as indicator(s) of their use of ASC.

\section{Preference and Attitudinal Variables}

Parents' attitude toward children walking or biking to school is assessed with a number of belief statements pertaining to various positive or negative behavioral outcomes associated with walking/biking and driving. All the attitudinal questions follow a 1-5 Likert scale. The higher value of their answer, the stronger the level of agreement they have with a particular belief statement. Factor analysis was used to derive an overall measure of attitude. A similar method was used to derive a measure of attitude toward car use.

As a way to assess their ASC preference, parents were asked about their level of agreement to the statement, "If possible, I'd like my child to walk or bike to school." Parents were also asked whether and what school-travel mode was considered when they moved to their current home. Having a particular transportation means in mind indicates that at least the parents considered using the particular transportation means that was feasible, and they had a certain level of intention to use it.

\section{$\underline{\text { Residential Location Decision Process }}$}

Parents were asked to rank the level of importance on a scale of 1 to 5 (1 being not important at all and 5 being extremely important) on 21 factors involved during their residential location decision-making process. Among those factors, four were directly relevant to active school commuting (ASC): proximity to school, walkability of the neighborhood, pedestrian and biking safety of the environment, and children's ability to walk or bike to school. Parents also identified the three most important reasons behind their decision to choose their current residence.

\section{Other Variables}

The set of other variables considered in the analysis include those pertaining to environmental conditions, school characteristics, and household and child characteristics.

Parents reported distance traveled between their residence and their children's schools. They also reported their assessment of their neighborhood layout in terms of a supportive walking or biking environment, and whether driving is the only safe way for their child to get to school. While these variables are not measures of objective environmental characteristics, they are indicative of the environmental conditions that better match parents' own perception and preference relevant to active school travel. Objective urban form variables measuring walkability around school sites are included in subsequent analyses.

Consideration of school characteristics involved school type (neighborhood school or choice school). Household socio-demographic variables included household income, 
employment status, education levels, race/ethnicity of adults in the household, and number of cars owned. Child characteristics included the child's age.

A table in Appendix B lists all questions and the corresponding attitudinal variables that the answers to those questions were used to capture. Development of these questions was informed by several recent studies that have made explicit the effort to analyze the independent influence attitudes have on travel behavior (Black et al. 2001; Schwanen and Mokhtarian, 2007). They were also tested for semantic clarity before they were sent out. In addition, this table provides an overview of all other variables used in the analysis. 


\subsection{SURVEY RESULTS}

\subsection{Overview of Survey Return}

In total, 5,500 surveys were mailed (126 were non-deliverables) and 1,197 were returned (21\% response rate).

Table 5-1 below indicates the representation of the survey respondents. A comparison of several socio-demographic and housing characteristics of the sample to those of the population suggests that the survey response reasonably represents all households with elementary school children in the school district. The respondents consist of predominantly white families ( $80 \%)$, who were homeowners (75\%), and had a median annual household income of about $\$ 60,000$ in 2007. These characteristics are representative of the overall racial and socio-economic makeup of the main city (Eugene, OR) served by the 4J School District.

Table 5-1:Comparison of Important Characteristics between Survey Respondents and Overall Population

\begin{tabular}{lll}
\hline Characteristics & $\begin{array}{l}\text { Population (all } \\
\text { households) }\end{array}$ & $\begin{array}{l}\text { Survey } \\
\text { Respondents }\end{array}$ \\
\hline $\begin{array}{l}\text { Family income } \\
\text { (median, 2007) }\end{array}$ & $\$ 60,785$ & $\sim \$ 60,000$ \\
$\begin{array}{l}\text { Housing type } \\
\text { (Rent vs. own) }\end{array}$ & $26 \%$ vs. 74\% & $25 \%$ vs. $75 \%$ \\
$\begin{array}{l}\text { School type } \\
\text { (neigh. vs. neigh_choice vs. }\end{array}$ & $63 \%$ vs. 15\% vs. 22\% & $\begin{array}{l}54 \% \text { vs. 17\%. } \\
\text { alternative.) }\end{array}$ \\
$\begin{array}{l}\text { Racial makeup } \\
\text { (White vs. Non-white) }\end{array}$ & $71 \%$ vs. 29\% & $\begin{array}{l}(70 \% \sim 85 \%) \\
(30 \% \sim 15 \%)\end{array}$ \\
\hline $\begin{array}{l}\text { (Wormation derived from American Community Survey for City of Eugene (American Fact Finder) and } \\
\text { 4J School District. }\end{array}$ & &
\end{tabular}

\subsection{Descriptive Findings}

A table in Appendix $\mathrm{C}$ provides descriptive statistics for major variables considered in this analysis.

\subsubsection{School-Travel Patterns}

Overall, 15.4 percent of parents in the sample reported that their child walked or biked to school (with or without an adult) at least three days a week, a similar frequency (14.4\%) for students who walk or bike from school. One in four respondents indicated that their children were bused to school at least three days a week. The majority of children in the survey, or about 55 percent, were driven to school in private vehicles (including carpool).

While only 15 percent of our respondents used ASC as the primary school-travel means, more than a third (36\%) of respondents replied that their children walked or biked to 
school at least one day a week. This suggests that, depending on the definition of "a usual mode for transportation,” there may be different findings when one-day-a-week vs. threeday-a-week use of ASC is considered. This study relies on the more stringent criterion, and focuses on those who reported using ASC three to five days per week.

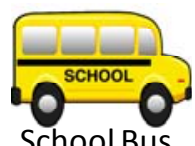

1 Day/Week

3 Days/Week

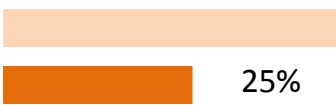

$44 \%$

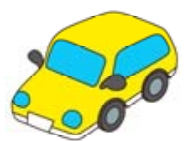

1 Day/Week

$70 \%$

3 Days/Week

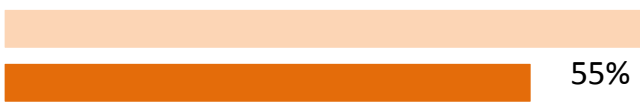

Personal Vehicle

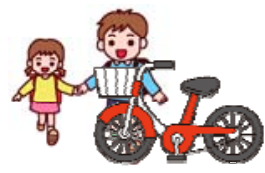

1 Day/Week

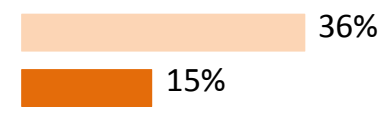

Figure 5-1: Statistics of School-Transportation Mode during a Typical Week

\subsubsection{Reasons behind using active school travel and driving to school}

The survey asked parents of children who use modes other than walking or biking as their primary travel mode (such as by car or by bus) about why they do not let their child walk or bike to school. The survey provided a list of reasons, and respondents were asked evaluate the importance or the applicability of the provided reasons on a scale of 1 to 5 (1 $=$ Not Important 5 = Extremely Important).

The most highly rated reason was, "Child is too young," followed by "Concern with traffic," and "Fear of child getting hurt." These findings echo those in the existing literature that safety concerns and distance to school were the strongest barriers that prevent children from walking or biking to school (see Figure 5-2).

Parents who did allow their children to walk or bike to school were asked about their reasons for doing so (Figure 5-3). The factors receiving the highest scores included, “Quality time spent with child” and, “Increase children’s physical activity.” 


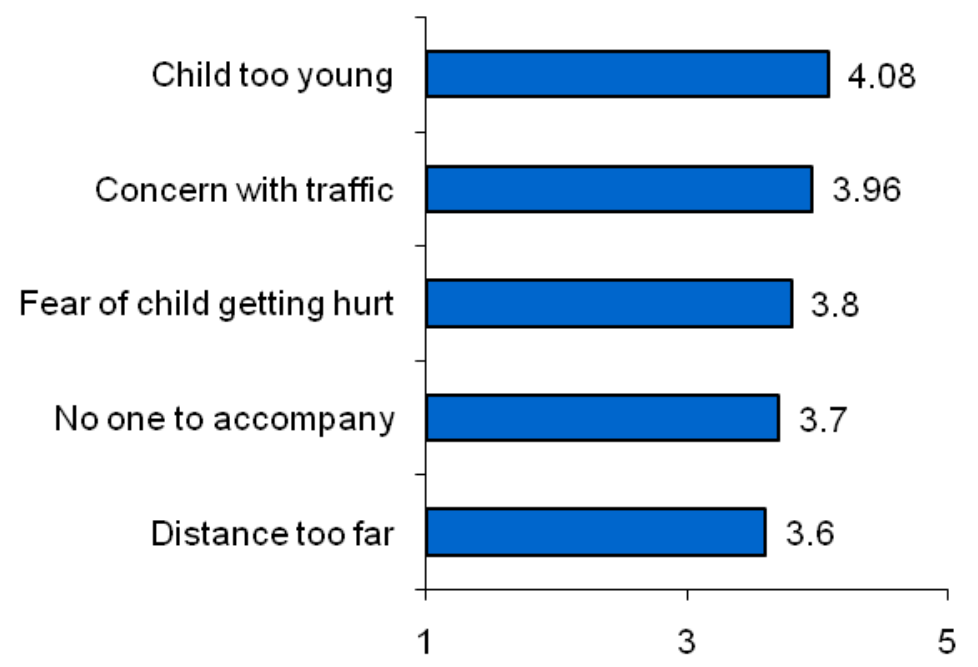

Figure 5-2. Top Five Most Important Reasons for not Using ASC

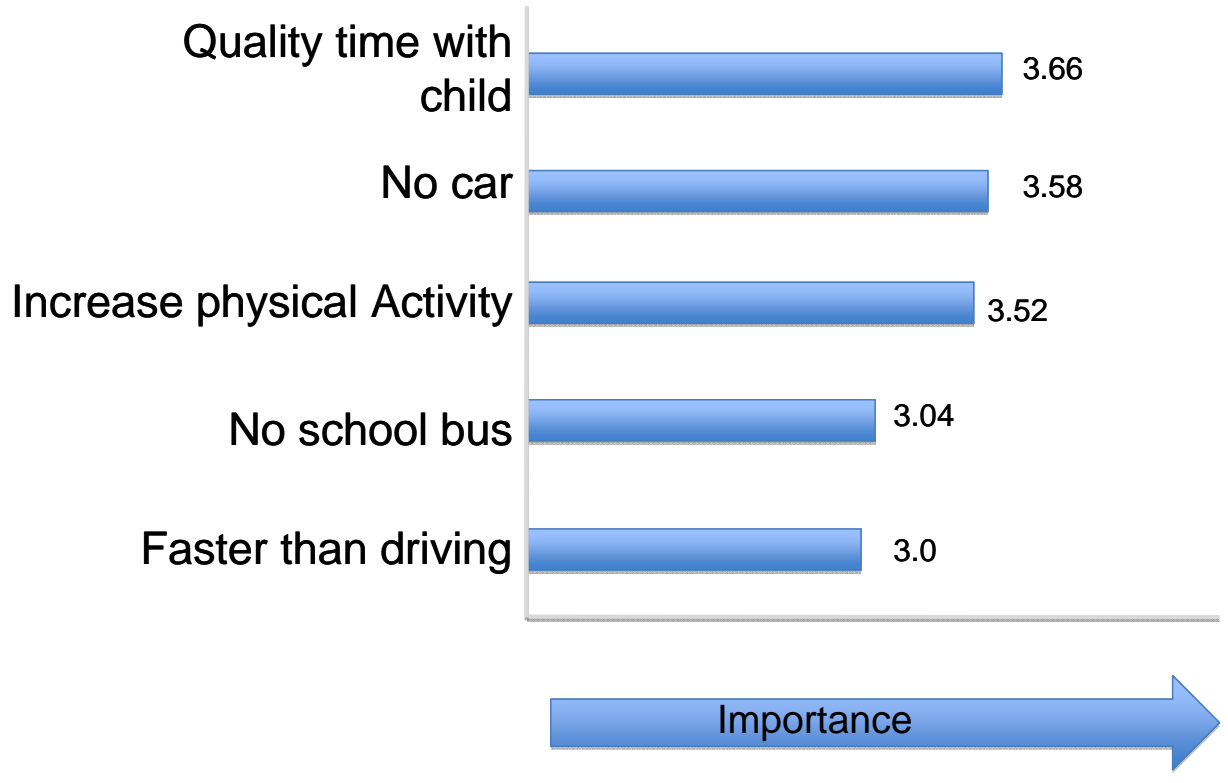

Figure 5-3. Top Five Most Important Reasons for Using ASC 


\subsubsection{Attitude toward Active School Commuting and Driving}

More than 70 percent of the parents surveyed agreed (28.7\%) or strongly agreed (42.4\%) with the statement that, "If possible, I prefer my child walk or bike to school." The statistics of this global measure of preference suggest prevalence of strong ASCpreference among parents.

Factor analysis was used to derive two attitudinal measures based on respondents' answers to more than a dozen belief statements. One measure indicates parents' attitude toward active school travel, and the other toward car/automobile use. These two measures are found weakly correlated $(\mathrm{R}=-0.159, p<0.001)$.

Parents' overall preference for children walking or biking to school is strongly and positively correlated with parents' attitude toward such behavior ( $\mathrm{R}=0.546, p<0.001)$, but its correlation with car attitude is weaker ( $\mathrm{R}=-0.273, p<0.001)$. Parents' overall preference for walking or biking to school is strongly correlated with their belief that, "Children walk/bike is good way to know neighborhood," $(\mathrm{R}=0.482, p<0.001)$ and with their belief that, "Driving to school contributes to environmental pollution" $(\mathrm{R}=0.419$, $p<0.001$ ). On the other hand, parents' overall ASC preference negatively correlates with their belief in the convenience and comfort brought by driving $(\mathrm{R}=-0.384, p<0.001)$ (see Table 5-2).

Table 5-2. Correlations between ASC Preference and Parent Attitudes

\begin{tabular}{|c|c|c|c|c|c|c|c|}
\hline \multirow{5}{*}{$\begin{array}{l}\text { preference } \\
\text { /intention }\end{array}$} & & \multicolumn{6}{|c|}{ Attitude toward active school travel } \\
\hline & Pearson & Factor & $\begin{array}{l}\text { Walking or biking } \\
\text { demonstrates } \\
\text { commitment to } \\
\text { protect } \\
\text { environment }\end{array}$ & $\begin{array}{l}\text { Kids walking or } \\
\text { biking is good } \\
\text { way to increase } \\
\text { physical activity }\end{array}$ & $\begin{array}{l}\text { Children may } \\
\text { develop auto- } \\
\text { dependent habit }\end{array}$ & $\begin{array}{l}\text { Children } \\
\text { walk/bike good } \\
\text { way to know } \\
\text { neighborhood }\end{array}$ & $\begin{array}{l}\text { Driving to } \\
\text { school } \\
\text { contributes to } \\
\text { envi. pollution }\end{array}$ \\
\hline & Correlation & $0.546 * * *$ & $.347 * *$ & $.351 * *$ & $.326 * *$ & $.482 * *$ & $.419 * *$ \\
\hline & $p$ & 0 & 0.00 & 0.00 & 0.00 & 0.00 & 0.00 \\
\hline & $\mathrm{N}$ & 1185 & 1185 & 1185 & 1185 & 1185 & 1185 \\
\hline & & \multicolumn{6}{|c|}{ Habitual tendency toward driving } \\
\hline ргенегепсе & rearsull & Factor & $\begin{array}{l}\text { Driving is more } \\
\text { comfortable than } \\
\text { walk/bike }\end{array}$ & $\begin{array}{l}\text { Prefer diriving } \\
\text { whenever I need } \\
\text { to go places in } \\
\text { this area }\end{array}$ & $\begin{array}{l}\text { Owning a car } \\
\text { contributes to a } \\
\text { comfortable } \\
\text { lifestyle }\end{array}$ & $\begin{array}{l}\text { I drive my car } \\
\text { as much as } \\
\text { others }\end{array}$ & $\begin{array}{l}\text { Car ownership } \\
\text { is status symbol }\end{array}$ \\
\hline \multirow[t]{3}{*}{ /intention } & Correlation & $-0.273 * * *$ & $-0.263 * *$ & $-.384 * *$ & -0.035 & $-.152 * *$ & $-.070 *$ \\
\hline & $p$ & 0 & 0.00 & 0.00 & 0.36 & 0.00 & 0.02 \\
\hline & $\mathrm{N}$ & 1175 & 1185 & 1175 & 1185 & 1185 & 1185 \\
\hline
\end{tabular}

**. Correlation is significant at the 0.01 level (2-tailed).

*. Correlation is significant at the 0.05 level (2-tailed).

The values of psychological variables were compared across different population groups (see Table 5-3). Parents' higher educational levels are associated with a more favorable 
attitude toward and stronger preference for walking/biking to school. On average, the group of families with the highest level of educational attainment (post graduate) had the most favorable attitude toward active school travel and the strongest preference for performing the behavior. Higher income levels, on the other hand, are associated with stronger habitual tendency for driving. The highest-income group $(>\$ 100,000)$ had the most favorable attitude toward driving. The group with income between $\$ 60,000$ and $\$ 99,999$ had the second-highest favorable attitude toward driving, but this group also had the most favorable attitude toward and strongest preference for active school travel.

Table 5-3. Mean Comparison of Attitude and Preference Scores among Population Groups

\begin{tabular}{|c|c|c|c|c|c|c|}
\hline \multirow[b]{2}{*}{ below $\$ 30,000$} & \multicolumn{2}{|c|}{$\begin{array}{c}\text { Attitude toward } \\
\text { ASC }\end{array}$} & \multicolumn{2}{|c|}{$\begin{array}{c}\text { Attitude toward } \\
\text { car/driving } \\
\end{array}$} & \multicolumn{2}{|c|}{ ASC Preference } \\
\hline & 211 & 0.059 & 209 & $-0.221 * * *$ & 210 & 3.962 \\
\hline between $\$ 30,000$ and $\$ 59,999$ & 301 & -0.039 & 295 & $-0.024 *$ & 299 & 3.960 \\
\hline between $\$ 60,000$ to $\$ 99,999$ & 357 & 0.098 & 354 & 0.005 & 356 & 4.107 \\
\hline above $\$ 100,000$ (reference) & 278 & 0.030 & 276 & 0.185 & 276 & 3.953 \\
\hline Did not complete high school & 9 & -0.529 & 8 & -0.145 & 8 & 3.125 \\
\hline high school/GED & 77 & $-0.153 *$ & 77 & 0.165 & 77 & $3.532 * *=$ \\
\hline Some college/associate & 225 & $-0.234 * * *$ & 221 & 0.071 & 224 & $3.652 * *$ \\
\hline college degree & 390 & $-0.002 *$ & 386 & 0.080 & 388 & $3.966 * *$ \\
\hline post graduate (reference) & 470 & 0.209 & 465 & -0.105 & 467 & 4.248 \\
\hline Don't know & 17 & 0.209 & 17 & -0.141 & 17 & 4.471 \\
\hline
\end{tabular}

\subsubsection{Consideration of School Travel in Residential-Location Choice}

Parents were asked whether and what school-travel mode was considered when they moved to their current home. Having a particular transportation means in mind indicates that at least the parents considered using the particular transportation means that was feasible, and they had a certain level of intention to use it.

Overall, about 78 percent of parents had thought about school transportation when they chose their current residence -- 60 percent of parents had just one type of travel means in mind (e.g., walking/biking, car, school bus) and 18 percent of parents had more than one type of transportation in mind when they chose their current residence. For respondents who considered school travel, interestingly, walking or biking to school was the most frequently mentioned travel means (44\%), followed by private automobile (37\%), and school bus (36\%).

The sequential order by which parents decided on school and location appears to affect the likelihood of parents thinking about school travel. For parents who made their housing decision in an effort to enable their children to go to a particular school (i.e., 
decide on a particular school before deciding on housing location), more than 93 percent of them contemplated at least one type of transportation means for their children's school travel. For parents who had not chosen a particular school before moving to their current residence, 80 percent of them had considered school travel. About 40 percent of respondents who had moved into their current place before their children were born considered what travel means they would use for their children to get to school.

\subsection{ASC Preference, residential-location choice, and school-travel behavior}

\subsubsection{Preference for Active School Commuting and Residential-Location Criteria}

It is clear that school travel was considered by the majority of the survey respondents. To examine how travel attitude may have affected families' residential-location choice, we relate the criteria parents used in their housing decision to their attitude toward active school commuting and driving.

Since proximity to school and neighborhood walkability greatly constrain the feasibility of children walking or biking to school, the analysis examined the degree to which parents considered those environmental factors in their housing decision. Parents were asked to rank the level of importance on a scale of 1 to $5(1=$ not important at all, $5=$ extremely important) for 21 factors that were likely to be considered in their residentiallocation decision-making process. Among those factors, four are directly relevant to active school commuting (ASC): proximity to school, walkability of the neighborhood, pedestrian and biking safety of the environment, and ability for my child to walk or bike to school.

The average importance scores parents reported for these 21 factors show that, when deciding where to live, parents considered factors such as safety from crime (particularly for their children), cost of housing, characteristics of housing unit, and reputation of neighborhoods as the most important factors. Parents placed more value on pedestrian and biking safety and environment walkability than on proximity to their neighborhood schools (see Figure 5-4).

Parents' concern about overall environmental conditions supportive of "ability for my child to walk/bike to school" was of low-level importance in their housing choice. The average score for this factor was only 2.46, the $15^{\text {th }}$ among the 21 factors examined here. The other three environmental factors related to ASC ranked $7^{\text {th }}$ (pedestrian and biking safety), $11^{\text {th }}$ (ease of walking and biking), and $12^{\text {th }}$ (proximity to neighborhood school), respectively.

There are differences in the importance levels attached to those environmental factors when parent groups are compared based on their expressed levels of preference for ASC. To measure their ASC preference the analysis used the agreement level the parents provided to the statement, "If possible, I'd prefer my child walk or bike to school." The stronger level of agreement parents had with the statement, the stronger preference they had for ASC.

While parents with higher levels of preference toward ASC placed higher value on environmental factors necessary for children walking or biking to school, the striking increases in the level of importance comes to the group of parents who had the strongest 
preference. Compared with other groups, this group of parents had much higher sensitivity toward neighborhood environmental conditions that affect the ability for their child to walk or bike to school. Particularly, they paid more attention to the environment walkability (i.e., "ease of walking and biking”) and the overall environmental "ability for child to walk or bike to school” (see Table 5-4).

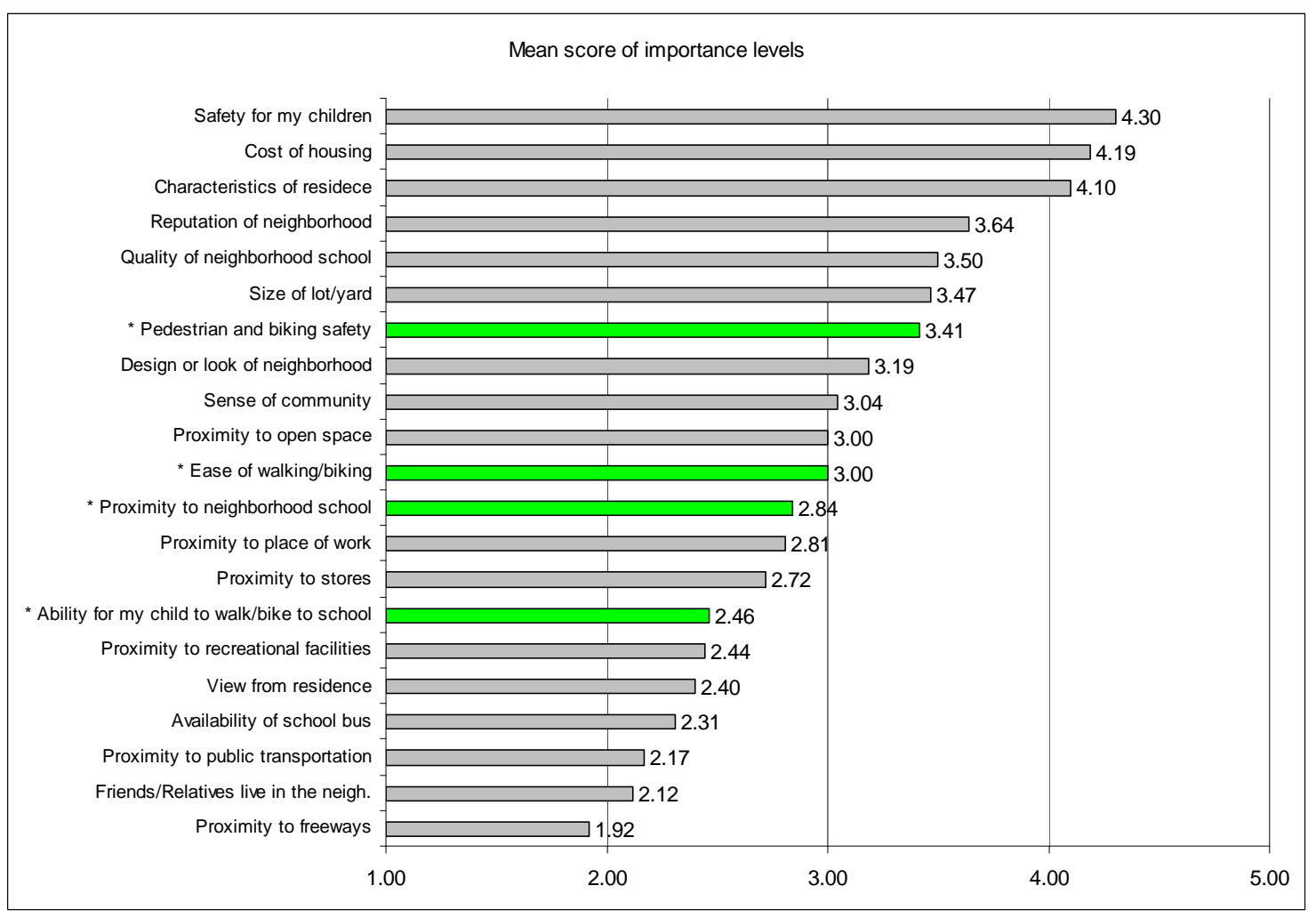

\section{Figure 5-4. Average importance scores for 21 factors considered in residential location choice}

Interestingly, while they clearly sought environments that could support ASC, parents with the strongest preference for ASC did not rank higher the condition "proximity to neighborhood schools" with respect to all other factors they considered in their residential-location choice. Table 5-4 shows the ranking of the ASC-related factors among the 21 factors for the five parent groups based on their ASC-preference levels. The "proximity to neighborhood schools" factor ranked similarly across the five groups, while the other three factors ranked much higher for the group of parents with the strongest preference for ASC. 
Table 5-4. Ranking of importance level among 21 factors in location decision

\begin{tabular}{lccccc} 
& \multicolumn{5}{c}{ Agreement with the ASC preference statement } \\
\cline { 2 - 6 } & strongly & & & strongly \\
& disagree & disagree & neutral & agree & agree \\
* Ability for my child to walk/bike to school & 21 & 21 & 21 & 18 & 12 \\
* Proximity to neighborhood school & 15 & 13 & 13 & 12 & 13 \\
* Ease of walking/biking & 16 & 16 & 15 & 11 & 7 \\
* Pedestrian and biking safety & 8 & 8 & 8 & 7 & 4 \\
\hline
\end{tabular}

\subsubsection{Using ASC Preference to Predict Home-School Distance}

To examine how behavioral preference affects residential-location choice, we analyze whether stronger preference for active school travel would predict a residential environment that better supports ASC. Two OLS regression models were used. The dependent variable in each of these models is a variable indicating home-school distance and neighborhood walkability, respectively.

Results from the two models are shown in Table 5-5. In the distance model, preference for ASC is associated with shorter home-school distance while many other household characteristics and school environment characteristics are controlled for. Very high income ( $>\$ 100,000)$, more cars owned by the household, and parent(s) being employed full time are associated with longer home-school distance. Households with minority member(s) tended to live closer to their children's school. The built environment around schools exerted strong influences on how close a child can live to his or her school. Schools located in mainly residential neighborhood (i.e., higher percentage of residential land) and in higher densities (i.e., smaller lots) witnessed shorter home-school distances for their students regardless of family characteristics. Finally, children attending their own neighborhood schools lived closer than those attending choice schools.

\section{Table 5-5. Output from OLS Regressions}

\begin{tabular}{|c|c|c|c|c|}
\hline & \multicolumn{2}{|c|}{ Distance Model } & \multicolumn{2}{|c|}{ Walkability Model } \\
\hline & $\mathrm{B}$ & Beta & $\mathrm{B}$ & Beta \\
\hline (Constant) & 4.72 & $* * *$ & 3.15 & $* * *$ \\
\hline Preference for ASC (1 5) & -0.25 & $-0.14 * * *$ & 0.12 & $0.11 * * *$ \\
\hline Household income below $\$ 30,000$ & 0.37 & 0.07 & -0.20 & -0.06 \\
\hline Household income between $\$ 30,000$ and $\$ 59,999$ & 0.06 & 0.01 & -0.15 & -0.05 \\
\hline Household income above $\$ 100,000$ or more & 0.37 & $0.07 * *$ & -0.05 & -0.02 \\
\hline Number of cars in household & 0.14 & $0.06 * *$ & -0.14 & $-0.10 * * *$ \\
\hline At least one household member is non-white & -0.31 & $-0.06 * *$ & 0.09 & 0.03 \\
\hline Highest education: post graduate degree & 0.06 & 0.01 & 0.03 & 0.01 \\
\hline Own the residence (yes $=1$ ) & -0.10 & -0.02 & 0.11 & 0.04 \\
\hline Parent(s) full time employed & 0.30 & $0.06 * *$ & 0.01 & 0.00 \\
\hline Total street length w/in quarter-mi of school & -0.12 & -0.06 & 0.10 & $0.07 *$ \\
\hline Percentage of residential land w/in quarter-mi of school & -1.31 & $-0.12 * * *$ & 0.59 & $0.09 * * *$ \\
\hline Average lot size w/in quarter-mi of school & -3.27 & $-0.13 * * *$ & -0.73 & $-0.05 * *$ \\
\hline Attending own neighborhood school & -1.30 & $-0.30 * * *$ & 0.06 & 0.02 \\
\hline Adj. R-square & 0.15 & & 0.07 & \\
\hline $\mathrm{N}$ & 1069 & & 1058 & \\
\hline
\end{tabular}


In the walkability model, again, the ASC-preference variable is associated with higher neighborhood walkability. There are, however, far fewer other household characteristics that were significantly affecting this environmental condition. The only other household variable found associated with neighborhood walkability is the number of cars owned by a household - the more cars owned by a household, the less walkable neighborhood the household lived in. School location registered statistically significant impacts on the kind of walkability that families could live in. When attending schools located in better connected streets (i.e., more streets within a quarter-mile of the school site) and mainly residential neighborhoods, households had a better environment to walk. Higher density surrounding a school site, however, did not help households live in a more walkable environment.

Comparing the standardized coefficients (Beta) reveals that, in the distance model, ASC preference is not the most important factor affecting home-school distance. The built environment around schools appears to have larger impacts on home-school distance. But in the walkability model, the ASC preference has the strongest influence on neighborhood walkability, compared with that of other variables. This is consistent with the earlier finding that with a higher level of ASC preference, parents particularly paid more attention to walkability in their location choice.

\subsubsection{Using ASC consideration during location process to predict ASC behavior}

By running a logistic model with "child walking or biking three days or more to school" as the dependent variable, we examine how consideration of ASC during the residential location process (i.e., the intention to use ASC upon moving to current residence) can predict the actual behavioral patterns of using ASC.

Table 5-6 reports the logistic model outcome. Having an intention to use ASC during location choice was the most significant predictor of later behavioral patterns $(B=1.69$, $\mathrm{p}<0.001, \exp (\mathrm{B})=5.42$ ), compared with environmental conditions, household characteristics, and the type of school attended. The odds of a child walking or biking to school at least three days a week increases by a factor of 5.42 if his or her parents thought about using ASC when moving to their current residence.

The important built-environment conditions necessary for ASC - short home-school distance and good neighborhood walkability - were associated with the likelihood of using ASC in expected ways. Home-school distance's influence on ASC was stronger and statistically more significant than that of neighborhood walkability. The builtenvironment characteristics surrounding a school site had little impact on the ASC behavioral pattern, except for the street-network-connectivity measure $(B=0.32, p=0.05$, $\exp (B)=1.38)$.

Other variables had associations with the dependent variable that was consistent with previous studies. Parents' safety concerns reduced the odds that their children were allowed to walk or bike to school. Older children were more likely to use ASC; the more cars a household owned, the less likely its child used ASC. Having adult(s) not working at home increased the likelihood of using ASC. Compared with households with income in the medium household-income range ( $\$ 60,000$ to $\$ 99,999)$, very low-income and very high-income households were both less likely to use ASC. 
Table 5-6. Logistic regression: predicting children walking/biking to school at least three days a week.

\begin{tabular}{lrlr}
\hline & \multicolumn{1}{l}{ B } & S.E. & exp(B) \\
\cline { 2 - 4 } ASC in mind when choosing current residence & 1.69 & $0.28^{* * *}$ & 5.42 \\
Preference for ASC (1 5) & 0.71 & $0.21^{* * *}$ & 2.03 \\
Neighborhood walkability (1 5) & 0.57 & $0.31^{*}$ & 1.77 \\
Home-school distance & -1.02 & $0.18^{* * *}$ & 0.36 \\
Safety concern (1 5) & -1.04 & $0.14^{* * *}$ & 0.35 \\
Total street length w/in quarter-mi of school & 0.32 & $0.16^{*}$ & 1.38 \\
Percentage of residential land w/ quarter-mi of school & 0.57 & 0.89 & 1.76 \\
Average lot size w/ quarter-mi of school & 2.08 & 2.24 & 7.98 \\
Age of child & 0.17 & $0.08^{* *}$ & 1.19 \\
Own the residence (yes=1) & -0.11 & 0.36 & 0.90 \\
At lease one adult not employed & 0.69 & $0.28^{*}$ & 2.00 \\
Household income below \$30,000 & -0.86 & $0.43^{* *}$ & 0.42 \\
Household income between \$30,000 and \$59,999 & -0.47 & 0.34 & 0.63 \\
Household income above \$100,000 or more & -1.13 & $0.37 * * *$ & 0.32 \\
Number of cars in household & -0.30 & $0.18^{*}$ & 0.74 \\
At least one household member is non-white & 0.18 & 0.32 & 1.20 \\
Highest education: post graduate degree & 0.29 & 0.28 & 1.34 \\
Attending own neighborhood school & 0.65 & $0.29 * *$ & 1.92 \\
Constant & -5.10 & 1.66 & 0.01 \\
\hline-2 Log likelihood & 420.61 & & \\
quasi R -square (Nagelkerke R Square) & 0.62 & & \\
N & 1050 & & \\
\hline
\end{tabular}




\subsection{RESULTS FROM INTERVIEWS \& FOCUS GROUPS}

This section summarizes the major themes around residential-location choice and school travel identified through conversations with parents, local planners, and other professionals.

\subsection{Findings from Parent Focus Groups}

\subsubsection{Accessibility to school in Residential-location choice}

Participants were asked to determine how proximity to locations was prioritized when they were deciding on residential location. Interestingly, many parents placed proximity to school in their top priority. A summary of proximity priorities is found in the table below:

Table 6-1: Parents' preferred housing priority

\begin{tabular}{c|c|c|c}
\hline Top Priorities & Second Priorities & Third Priorities & $\begin{array}{c}\text { Places to avoid } \\
\text { living by }\end{array}$ \\
\hline School quality & $\begin{array}{c}\text { School Location } \\
\text { Recreational } \\
\text { Opportunities (parks, } \\
\text { bike paths...) }\end{array}$ & Shopping & $\begin{array}{c}\text { Highway } \\
\text { Interchanges }\end{array}$ \\
Family & $\begin{array}{c}\text { Prisons } \\
\text { Sewage Treatment } \\
\text { Plants }\end{array}$ \\
\hline
\end{tabular}

Although school quality was a top priority for most parents, many parents stated that Eugene's school-choice policy made proximity to their desired school less important. This sentiment was reinforced by parents who commented that Eugene is not a large enough community for transportation to be a barrier. It only takes 15-20 minutes to drive across the entire town, and many parents were willing to take the time to drive so their child could attend the desired school.

Many participants acknowledged that they were not able to find a residence that matched their ideal location in Eugene. Many cited affordability as the major reason for buying/renting their current home and noted that transportation, in general, was not a high priority. Others made a point of saying they wanted to be near bike paths, but often cited that they enjoyed the paths as recreational opportunities more than as transit routes. Parents who frequently used walking or biking as their transportation mode were adamant about living near a bike path and did not sacrifice that characteristic when deciding on their residence.

Landscape and neighborhood were also major factors when deciding on location. Many participants spoke about the trees in the South Hills in Eugene; some parents liked the 
forested feel and wanted to live in the hills whereas others felt the trees made the area too dark and unsafe.

Parents also discussed neighborhood attributes as an important characteristic when deciding on a home. A few parents mentioned that it is rare to meet the neighbors before purchasing/renting a home and that neighborhood safety is judged through aesthetics. If the neighborhood appears neat and clean, parents look at that as a sign of safety. The visual appeal of the neighborhood was a major factor in desirable housing.

\subsubsection{School Transportation}

In general, children used the mode of transportation the parent most commonly used. Many parents cited walking/biking as their preferred mode of transportation. However, some parents did not feel that walking or biking was a valid option to get their child to school due to conflicts of daily schedule along with the availability of school choice.

Overall, many parents admitted that their reasons were "excuses" and their child could walk or bike if necessary. One frequent comment from parents who expected their child to walk/bike to school but were driving instead was that they were unaware of other students in their neighborhood making the same trip and did not want their child to travel alone. Parents contributed this situation to $4 \mathrm{~J}$ 's school-choice policy, where it is possible for six children in one neighborhood to potentially go to six different schools throughout Eugene. When asked if they had looked into finding other families in their neighborhood in a similar situation, many parents admitted that they had not tried, but because they do not see children walking/biking in the morning they assumed that children do not walk/bike to school in their neighborhood. The following sections detail the key points brought up during the discussion with parents regarding residential-location choice and school travel.

There was discussion about the parents' anticipated mode of school travel versus the mode they actually use. This question was related to survey data that shows that although 28 percent of parents thought their children would walk/bike to school, only 15 percent actually do. Each discussion group included parents who were using the mode they expected and those using a different mode. Most of the parents using a different mode were currently driving and thought they would walk/bike or bus.

\section{Time constraints}

The most common reason parents cited was time constraints. In the 4J School District, elementary schools start at different times. Some parents commented that the schools began very early and that their child would have to wake up too early if they decided to walk or bike. Other parents who were driving had initially considered the bus, but mentioned that the bus route was not conducive to their residential location; the bus ride would be much longer for their child then driving.

Trip chaining

Trip chaining was also a popular reason for driving a child to school. Many parents stated that they dropped their child off on their way to work or shopping. Therefore, the trip to school was not an additional trip in their minds. Parents who had more than one child, especially if they were in different schools, said that driving was the only manageable way to get all their children to school. For example, one parent who lived in North Eugene had three children in three different schools in South Eugene. Even without 
distance being a factor, that parent commented how driving was the only way to assure that all the children got to school on time with supervision. The parent would not have been able to drop each child off using individual walking/biking trips.

Some parents commented that they were involved in school activities with the child or worked at the school. In these situations, the child's travel to school was not an additional trip for the parent. Parents also mentioned their children having a number of after-school activities. Depending on the location and time of the activity, a personal vehicle was sometimes the only way to transport the child.

Natural environmental factors

Natural environmental factors (e.g., hills, weather, etc.) were also popular reasons for driving. Many parents stated that the distance between home and school is not unreasonable, but a hill makes it impossible for their child to walk or bike. The inconvenience of the hill was magnified by the loads that the children often have to carry (backpacks, instruments and laptops).

Safety

Parents discussed neighborhood safety and the safety of Eugene in general. Some parents were not comfortable allowing their children to walk/bike to school because of traffic safety or "stranger danger." Parents had varying opinions of what was safe; some parents admitted to never allowing their children on a school bus because of "bullying," although some parents thought that the bus was safe because they know the other children and bus driver. Other parents were concerned about the safety of the bike paths and mentioned that homeless people using the bike paths makes them uneasy. In general, it seemed that many parents who always drove wanted to have somebody they trusted "watching" their child, and if that could not happen without driving, they would drive. For parents who walked or biked with their child, they were generally less concerned with safety, particularly as the child got older. The parents who accompanied their children walking or biking to school also felt more comfortable letting their child walk or bike alone to and from school.

Some parents said that they drove their children because of health reasons. One parent had an autistic child that could not physically walk to school. This parent also said that she had to drive to work (she dropped off her child on the way to work) because she might have to return to the school quickly to care for her son. In this situation, safety was discussed as related to the health of the child.

Many parents also admitted that they were more protective of their child then they thought they would be. The parents spoke about how the environment is "not like it used to be," and were convinced that walking/biking is more dangerous in today's society. One parent cited that statistically it's safer to walk/bike to school today than it was 50 year ago, but increased media about traffic danger/kidnapping has caused parents to be overcautious. Many parents agreed with this point.

\subsubsection{Reasons for Walking or Biking}

The parents who have their children walk/bike to school spoke about how important walking and biking was whether it was for physical activity or independence. One parent mentioned that she lets her 10-year-old daughter bike to school alone on a bike path and admitted that other parents think this is a bad decision. She mentioned that by letting her 
daughter bike to school alone, her daughter is gaining independence. The parent also commented that she had discussed safety and "street smarts" with her daughter and believes her daughter is responsible enough to walk or bike.

Other parents preferred walking or biking over driving due to ease or personal choice. Several parents mentioned that it was easier for their child to walk or bike, rather than take the bus or be driven to school. The parents who mentioned it was easier seemed to make a conscious effort to walk/bike and did not mention that it was quicker for them to walk/bike than drive. Some parents talked about environmental responsibility and how walking and biking with children can set the standards for the child's travel mode as they grow up.

\subsubsection{Reasons for Driving}

Some parents said that the physical environment around the school "forced" them to drive their child. Some schools have fences around the property, which only allows for one entrance. Parents commented on how this layout makes it more difficult to walk/bike to school. This layout also can make a driveway to the school congested and dangerous for pedestrians and bicyclists, resulting in more parents driving to school.

Throughout the discussion, many parents who felt "forced" to drive their children to school asked how it was possible for other parents to walk/bike with their children. Many parents believed that elementary school was simply too early for kids to walk/bike (especially alone), but might consider changing their child's transportation mode as they get older. Some parents even mentioned choosing their residence by planning ahead. One parent spoke of how they drive their children now, but anticipate their children walking/biking to middle and high school.

\subsection{Findings from Community Interviews \& Focus Group}

\subsubsection{Community Land-Use Planning and Residential Development}

The METRO plan is City of Eugene's main document for long-term planning. This document provides a 20-year plan and zoning regulations for the density and types of residences within Eugene. The current plan stresses concentrated development, which suggests that existing residential areas are sites for development, rather than building in areas currently undeveloped.

Neighborhoods are prioritized for development based on their proximity to commercial services. School location plays little role in higher density development. However, school proximity plays a role in mixed-use centers, where residences and commercial operations are on the same property.

Housing is difficult to find in Eugene, with low vacancy rates and expensive housing nearer the city center. One respondent said that 75 percent of low-income housing needs are not met in Eugene, making affordability in the district quite difficult. Many families are forced to locate in neighboring school districts, including Bethel/Danebo and Springfield.

Under the METRO plan, City of Eugene plans for concentrated development. As a drawback, older established neighborhoods with strong neighborhood associations block 
higher-density development. These areas typically have high housing demand and very low vacancy rates, leading to more expensive housing and making it difficult for new families to move in. Newer families locate in concentrated areas of newer development typically located on Eugene's periphery, causing marked shifts in school enrollment.

Newer residents with young children find it difficult to locate in established neighborhoods. As residents in established neighborhoods age, fewer students attend elementary school year-on-year. The school may be forced to close under these circumstances, particularly if the facility is aging and maintenance costs increase. The school district and City of Eugene plan for demographic changes, but normally only for the next 10 years or less. This makes it difficult to identify exactly where families will locate.

Large-scale and planned-unit developments provide the easiest way for schools and city planners to plan for future enrollment. With these types of developments, City of Eugene reviews the application in-depth and has a better understanding of how the development impacts city services and demographics. Under these developments, the city knows the types of housing units present, the street infrastructure needed for the neighborhood and possible location for future schools. The school district is able to collect this information from the city. Thus far, one interview respondent said interaction between the city and school district has been limited. Even knowing the scale of a development it can be problematic to identify which type of school (elementary, middle school, alternative) is needed, prior to residents moving into the housing.

The METRO plan contains provisions for concentrated development without expanding the urban growth boundary around the city to allow development on undeveloped land. With less available undeveloped land, the school district has a difficult time finding large enough sites for future school development. In other communities, school districts may purchase property for future school development. While that is possible in Eugene, the METRO plan and high land demand make purchase difficult. Schools are forced to compete against developers for undeveloped real estate. The city's METRO plan has no provision to reserve land for public use unless a particular parcel is specified as such in the plan.

\subsubsection{School Planning and Policies}

\section{School Siting}

The school district has five-year forecasts for enrollment numbers and five- to 15-year planning for school siting. Demographics can fluctuate, making school siting somewhat problematic. The school district uses several factors to determine school sites to develop or close:

Building capacity: Ideally, the school needs enrollment numbers above 300 to provide the right types of programs for students.

Lot size: Schools usually require properties up to 15 acres for schools. Under this size, parking, playground and classroom size become limited.

Building Condition: Schools vary in construction over time. Newer facilities are typically in better condition for students and teachers. 
Operating Costs: Older schools have higher maintenance costs. In addition, many schools are small and cannot accommodate increased enrollments. Funding is a very important consideration for school development and closures.

Schools within neighborhoods are more attractive to families. Additionally, schools near parks or open space are looked upon favorably by parents. The proximity of schools to commercial centers is of less importance.

Under the current system, schools go through the same development and review process with City of Eugene as a planned-unit development or subdivision. State and local policies require newer school sites to submit a traffic-impact study along with the development. When siting schools, the district largely works with the city on its own terms. Coordination between the city’s planning department and 4J School District is limited, in terms of sharing population projections, demographic trends and utilizing the pre-development conference system available in the city to handle development issues

\section{School Catchment Boundary Delineation}

School-district boundaries are determined by a boundary-review committee within the school district, along with consultants. The superintendent may make very minor adjustments, but anything major must go to the committee. Boundaries, if adjusted are redrawn drawn every five years.

The school-choice option makes it difficult to draw boundaries (see school-choice policy section below). Some schools have lower enrollments because of school choice and thus require larger boundaries. Popular schools of choice typically have small boundaries.

With recent school closures, including Santa Clara in north Eugene and Laurel Hill in southeast Eugene, school boundaries and enrollments fluctuate. The school boundaries may change every five years to keep enrollments more consistent at schools, but school consolidation can make someone live closer to one school, yet be assigned to another.

\section{School-Choice Policy}

Under the school-choice policy, parents must arrange transportation for the child. This can make it difficult for the district to site schools, since enrollment may come from other areas of the city. Also, due the demand for school choice, the 4J School District has capped transfers to less than 5 percent for middle schools and 7.5 percent for high schools. At present, there is no set policy to limit transfers between elementary schools.

\section{School-Transportation Policies}

The 4J School District only provides busing to elementary schoolchildren attending their assigned neighborhood school and who live at least one mile away from the school. The district is looking into ways to provide "regional" transportation. An example of this "regional" transportation is providing busing to all students within the southern part of Eugene to any school within the southern part of Eugene.

Children attending a school of choice, regardless of distance, may not use the school bus. During the focus group, participants felt that school choice was one of the main reasons for a high driving rate in Eugene. Participants also mentioned that because Eugene is not 
a large town and driving distances/times are relatively small, parents did not feel that driving was difficult or overly time consuming

\subsubsection{Programs Promoting Active School Commuting}

Currently there are several programs functioning in the school district to promote alternative school transportation.

Smart Ways to School promotes alternative solutions for trips to school, specifically a walk/bike pool, busing and carpooling. Schools participate in the program by distributing materials (usually flyers) in "back to school" information, at school orientation, or by placing flyers by offices or at events. Participation rates vary between schools.

Smart Ways to School provides a database of parents interested in using group modes of transportation to get their children to school. Few parents are currently aware of the program. City of Eugene worked with Smart Ways to School on one school project. The city brought in transportation engineers, rated safety and identified cut-through paths to improve conditions. They also advise on what changes are legal, acceptable, and need signage. The city also helped publicize the project.

Safe Routes to School works alongside Smart Ways to School in promoting alternative transportation modes to and from schools. Safe Routes also works to improve the vehicular traffic congestion immediately around a school. Examples of ways to reduce congestion include: designating specific pick-up and drop-off points for parents transporting their children by car; improving walking and biking access routes to the school; and surveying and educating parents about alternative transportation options.

Normally, the stronger participation rates at a school are a reflection of dedicated staff members or parents. At present, Safe Routes to School is attempting to get one physical education teacher to be the in-school contact at each school.

At present, Safe Routes to School promotes “children's health" as the primary reason for walking and biking. Safe Routes particularly reached out to the "wellness" committee of the school district for this purpose. Safe Routes also has worked with Eugene city planning on technical design and transportation engineering to promote walking/biking to school.

Federal, state and local policies consider sidewalk and crosswalk improvements for distances of $1 / 4$ mile for walking and one mile for biking. This is a disconnect within school-transportation planning that the distance between $1 / 4$ mile and a mile from the school is not planned for pedestrian use or school buses. Depending on the size of any development, it can trigger a traffic-impact analysis. Part of that analysis is to accommodate for school-transportation safety.

Within City of Eugene, transportation planners work to promote pedestrian and bicycle connectivity. The school district deals normally with improvements immediately near the school (usually within two blocks), while other improvements are independent projects not related to $4 \mathrm{~J}$. At present, there is no formal connection between transportation planners within Eugene and the 4J school board. 


\subsection{SUMMARY AND CONCLUSIONS}

The findings in this study lend support to the contention that residential-location choice provides a mechanism by which ASC preference exerts influence on later behavioral patterns. While many environmental characteristics (e.g., home-school distance, safety, walkability) still play a role in affecting parents' decisions, consideration of using ASC early on greatly influences later travel behavior.

Integration of the residential-location process into school-travel-behavior study helps gain a better understanding of many of the environmental characteristics' impacts on school travel. For example, the research shows that the land-use mix conditions around a school site did not register independent and direct influence on the likelihood of a household using ASC, which is consistent with other studies (EPA, 2003; McMillan, 2007). This study, however, also reveals that such environmental conditions had great influence on whether families can live close to school and have a walkable environment in the first place. Thus, the influence of land-use mix on school travel could be overlooked due to its correlation with other environmental conditions.

The improved understanding of the decision-making process of residential location also helps reveal the limitation in current environment-based strategy for changing schooltravel behavior. Currently, most of the Safe Routes to School programs devote the majority of their resources to the improvement of physical infrastructure, which is likely to impact walkability. Compared to that of home-school distance and preference, the limited influence of the walkability variable on travel patterns may help explain some of the less encouraging results of the environmental interventions reported in recent studies (see, e.g., Boarnet et al., 2005).

Allowing more children to live close to their schools clearly has stronger impacts on changing school-travel behavior than improving environmental walkability. School siting policies have been used to require schools be located close to residential neighborhoods. While the research findings provide supportive evidence to such a policy's effectiveness, it should note that home-school distance was affected by a number of variables beside school-environment characteristics, such as parents' employment status, number of cars owned, household income, etc. Such finding reflects the many tradeoffs that a family faces in determining where to live, and it suggests that parents' location choice is affected by not only the conditions surround a school site but also the spatial configuration of housing opportunities and land uses in the entire community. This understanding clearly calls for a better collaboration between community land-use planning and school planning and a more comprehensive strategy in the use of environmental interventions for changing school-travel behavior.

While environmental conditions are necessary for ASC, they are not sufficient. A strong motivation (e.g., strong preference and intention) seems essential for sustaining ASC. The research shows a strong predictive power that the intention to use ASC upon moving to a current residence has on later use of ASC. This finding reinforces the notion that education and encouragement are two critical components in addition to physical environment to ensure the success of many programs advocating Safe Routes to School. The better explanatory power of ASC preference than environment walkability indicates 
a need to change the exiting strategy and invest more resources to changing parent attitude and preference. 


\section{References:}

Ahmadi, E., \& Taniguchi, G. (2007). Influential factors on children's spatial knowledge and mobility in home-school travel - A case study in the city of Tehran. Journal of Asian architecture and building engineering, 6(2), 275-282.

Ajzen, I. (1991). The theory of planned behavior. Organizational Behavior and Human Decision Processes, 50, 179-211.

Ajzen, I. (2001). Nature and operation of attitudes. Annual Review of Psychology, 52, 2758.

Ajzen, I. (2002). Perceived behavioral control, self-efficacy, locus of control, and the theory of planned behavior. Journal of Applied Social Psychology, 32, 665-683.

Ajzen, I., \& Fishbein, M. (1980). Understanding attitudes and predicting social behavior. Englewood Cliffs, NJ: Prentice-Hall.

Alfonzo, M. A. (2005). To Walk or Not to Walk? The Hierarchy of Walking Needs. Environment and Behavior, 37(6), 808-836.

Anable, J., \& Gatersleben, B. (2005). All work and no play? The role of instrumental and affective factors in work and leisure journeys by different travel modes. Transportation Research Part A: Policy and Practice, 39(2-3), 163-181.

Armitage, C. J., \& Conner, M. (2001). Efficacy of the Theory of Planned Behaviour: A meta-analytic review. British Journal of Social Psychology, 40, 471-499.

Bagley, M., \& Mokhtarian, P. (2002). The impact of residential neighborhood type on travel behavior: A structural equations modeling approach. The Annals of Regional Science, 36 (2), 279-297.

Bamberg, S., Ajzen, I., \& Schmidt, P. (2003). Choice of Travel Mode in the Theory of Planned Behavior: The Roles of Past Behavior, Habit, and Reasoned Action. Basic \& Applied Social Psychology, 25(3), 175.

Bamberg, S., \& Schmidt, P. (2003). Incentives, Morality, Or Habit? Predicting Students' Car Use for University Routes With the Models of Ajzen, Schwartz, and Triandis. Environment and Behavior, 35(2), 264-285.

Bhat, C.R. \& Guo, J.Y (2007). A Comprehensive Analysis of Built Environment Characteristics on Household Residential Choice and Auto Ownership Levels, Transportation Research Part B, 41(5), 506-526.

Black, C., Collins, A., \& Snell, M. (2001). Encouraging Walking: The Case of Journeyto-school Trips in Compact Urban Areas. Urban Studies 38(7), 1121-1141.

Boarnet, M. G., Anderson, C. L., Day, K., McMillan, T., \& Alfonzo, M. (2005). Evaluation of the California Safe Routes to School legislation: Urban form changes and children's active transportation to school. American Journal of Preventive Medicine, 28(2, Supplement 2), 134-140.

Boarnet, M. G., Day, K., Anderson, C., McMillan, T., \& Alfonzo, M. (2005). California's Safe Routes to School Program. Journal of the American Planning Association, 71(3), 301-317.

M. Boarnet, K. Day, C. Anderson, T. McMillan, \& M. Alfonzo, “California's Safe Routes to School Program: Impacts on Walking, Bicycling, and Pedestrian Safety," Journal of the American Planning Association, volume 71, issue 3, Summer, 2005, pp. 301-317. 
Booth, M. L., Chey, T., Wake, M., Norton, K., Hesketh, K., Dollman, J., et al. (2003). Change in the prevalence of overweight and obesity among young Australians, 1969-1997. American Journal of Clinical Nutrition, 77(1), 29-36.

Buunk, B. P. (1997). Social Comparison in Health and Illness: A Historical Overview In B. P. Buunk, F. X. Gibbons \& L. E. Associates (Eds.), Health Coping and Wellbeing: Perspectives from Social Comparison Theory. Mahwah, NJ Lawrence Erlbaum.

Cao, X., Handy, S. L., \& Mokhtarian, P. L. (2006). The Influences of the Built Environment and Residential Self-Selection on Pedestrian Behavior: Evidence from Austin, TX. Transportation, 33(1), 1-20.

Cervero, R., and R. Gorham (1995). "Commuting in trasit versus automobile neighborhoods." Journal of the American Planning Association 61(2): 210-224.

Choocharukul, K., Van, H. T., \& Fujii, S. (2008). Psychological effects of travel behavior on preference of residential location choice. Transportation research. Part A, Policy and practice, 42(1), 116-124.

Collins, C. M., \& Chambers, S. M. (2005). Psychological and Situational Influences on Commuter-Transport-Mode Choice. Environment and Behavior, 37(5), 640-661.

Cooper, A. R., Page, A. S., Foster, L. J., \& Qahwaji, D. (2003). Commuting to school: Are children who walk more physically active? American Journal of Preventive Medicine, 25(4), 273-276.

Crane, R. C. (2000) The Influence of Urban Form on Travel: An Interpretive Review. Journal of Planning Literature. Vol. 15, No. 1, 3-23

Crane, R. C., and Marlon G. Boarnet (2001). Travel by Design, Oxford University Press US.

Davison, K., \& Lawson, C. (2006). Do attributes in the physical environment influence children's physical activity? A review of the literature. International Journal of Behavioral Nutrition and Physical Activity, 3(1), 19.

Dellinger, A. M. (2002). Barriers to children walking and biking to school-United States, 1999. Morbidity and Mortality Weekly Report, 51(32), 701.

Dubay, A. (2003, September 7). See Dick and Jane Sit in Traffic. The Press Democrat.

Dumbaugh, E., \& Frank, L. D. (2007). Traffic safety and Safe Route to Schools: Synthesizing the empirical evidence. Transportation Research Record(2009), 8997.

Environmental Protection Agency (2003) Travel and environmental implications of school siting.

Ewing, R., \& Green, W. (2003). Travel and environmental implications of school siting. Washington, DC: U.S. Environmental Protection Agency.

Ewing, R., Schroeer, W., \& Greene, W. (2004). School location and student travel analysis of factors affecting mode choice. Transportation Research Record, 1895(1), 55-63.

Eyles, J. (1990). "Objectifying the subjective: the measurement of environmental quality." Social Indicator Research 22: 139-153.

Friedman, B., Stephen P. Gordon and John B. Peers (1992). The Effects of Neotraditional Neighborhood Design on Travel Characteristics. Transit Oriented Development, Impacts on Travel Behavior, . Calthorpe Associates. 
Fujii, S., \& Gärling, T. (2003). Application of attitude theory for improved predictive accuracy of stated preference methods in travel demand analysis. Transportation Research Part A: Policy and Practice, 37(4), 389-402.

Gardner, B., \& Abraham, C. (2007). What drives car use? A grounded theory analysis of commuters' reasons for driving. Transportation Research Part F: Traffic Psychology and Behaviour, 10(3), 187-200.

Gardner, B., \& Abraham, C. (2008). Psychological correlates of car use: A meta-analysis. Transportation Research Part F: Traffic Psychology and Behaviour, 11(4), 300311.

Garling, T., \& Schuitema, G. (2007). Travel Demand Management Targeting Reduced Private Car Use: Effectiveness, Public Acceptability and Political Feasibility. Journal of Social Issues, 63, 139-153.

Greenwald, M. \& M. Boarnet, (2002) “The Built Environment as a Determinant of Walking Behavior: Analyzing Non-Work Pedestrian Travel in Portland, Oregon,” Transportation Research Record, number 1780, pp. 33-42.

Handy, S., Cao, X. \& Mokhtarian, P.(2006). Self-Selection in the Relationship between the Built Environment and Walking. Journal of the American Planning Association, 72(1), 55-74.

Johansson, M. (2006). Environment and parental factors as determinants of mode for children's leisure travel. Journal of Environmental Psychology, 26(2), 156-169.

Kaiser, F. G., \& Gutscher, H. (2003). The Proposition of a General Version of the Theory of Planned Behavior: Predicting Ecological Behavior. Journal of Applied Social Psychology, 33(3), 586-603.

Kerr, J., Rosenberg, D., Sallis, J. F., Saelens, B. E., Frank, L. D., \& Conway, T. L. (2006). Active Commuting to School: Associations with Environment and Parental Concerns. Medicine \& Science in Sports \& Exercise, 38(4), 787-794.

Kestens, Y. (2004). Why families move and what do they choose: an analysis of singlefamily property buyers. Unpublished Unpublished dissertation. Laval University.

Khattak, A., \& Rodriguez, D. (2005). Travel behavior in neo-traditionai neigbborhood developments: A case study in U.S.A. Transportation Research A, 39\{6), 481-500.

Kitamura, R., Patricia Mokhtarian, and Laura Laidet (1997). "A micro-analysis of land use and travel in five neighborhoods in the San Francisco Bay Area." Transportation Research Part D: Transport and Environment 24: 125-158.

Klöckner, C. A., \& Matthies, E. (2004). How habits interfere with norm-directed behaviour: A normative decision-making model for travel mode choice. Journal of Environmental Psychology, 24(3), 319-327.

Krizek, K. (2000). Pretest-posttest strategy for researching neighborhood-scale urban form and travel behavior. Transportation Research Record, 1/22, 48-55.

Levine, J., \& Inam, A. (2004). The market for transportation-land use integration: Do developers want smarter growth than regulation allows? Transportation. 31(4), 409-427.

Lindenberg, S., \& Steg, L. (2007). Normative, Gain and Hedonic Goal Frames Guiding Environmental Behavior. Journal of Social Issues, 63, 117-137. 
Lorenc, T., Brunton, G., Oliver, S., Oliver, K., \& Oakley, A. (2008). Attitudes to walking and cycling among children, young people and parents: a systematic review. Journal of Epidemiol Community Health, 62(10), 852-857.

Markowitz, E. M., \& Doppelt, B. (2009). Reducing greenhouse gas emissions through behavioral change: An assessment of past successes in energy use, transportation and water consumption. Eugene, OR: University of Oreogn, Institute for a Sustainable Environment

McCormack, G. R., Cerin, E., Leslie, E., Du Toit, L., \& Owen, N. (2008). Objective Versus Perceived Walking Distances to Destinations: Correspondence and Predictive Validity. Environment and Behavior, 40(3), 401-425.

McDonald, N. C. (2006). Exploratory Analysis of Children's Travel Patterns. Transportation Research Record, 1997(2006), 1-7.

McDonald, N. C. (2007a). Active Transportation to School: Trends among U.S. Schoolchildren, 1969-2001. American Journal of Preventive Medicine, 32(6), 509-516.

McDonald, N. C. (2007b). Children's mode choice for the school trip: the role of distance and school location in walking to school. Transportation, 35(1), 23-35.

McDonald, N. C. (2007c). Travel and the social environment: Evidence from Alameda County, California. Transportation Research Part D: Transport and Environment, 12(1), 53-63.

McMillan, T. (2003). Walking and urban form: modeling and testing parental decisions about children's travel. Unpublished Ph.D. thesis, University of California-Irvine.

McMillan, T., Day, K., Boarnet, M., Alfonzo, M., \& Anderson, C. (2006). Johnny walks to school-does Jane? Sex differences in children's active travel to school. Children Youth Environment, 16(1), 75-89.

McMillan, T. E. (2005). Urban Form and a Child's Trip to School: The Current Literature and a Framework for Future Research. Journal of Planning Literature, 19(4), 440-456.

McMillan, T. E. (2007). The relative influence of urban form on a child's travel mode to school. Transportation Research Part A: Policy and Practice, 41(1), 69-79.

Merom, D., Tudor- Locke, C., Bauman, A., \& Rissel, C. (2006). Active commuting to school among NSW primary school children: implications for public health. Health \& place, 12(4), 678-687.

Mokhtarian, P. L. and Cao, X. (2008). Examining the impacts of residential self-selection on travel behavior: A focus on methodologies. Transportation Research B, 43 (3), 204-228.

Molnar, B. Gormaker, S. Bull, F. \& Buka, S. (2004) unsafe to play? Neighborhood disorder and lack of safety predict reduced physical activity among urban children and adolescents. American Journal of Health Promotion 18, 378-386.

Næss, P., 2005. Residential location affects travel behavior-but how and why? the case of Copenhagen metropolitan area. Progress in Planning 63, 167-257.

Newman, P \& Kentworthy (1999) Sustainability and Cities: Overcoming Automobile Dependence. Island Press.

Nordlund, A. M., \& Garvill, J. (2003). Effects of values, problem awareness, and personal norm on willingness to reduce personal car use. Journal of Environmental Psychology, 23(4), 339-347. 
O'Brien, C. (2003). Transportation...That's Actually Good for the Soul. National Center for Bicycling and Walking (12-03-1).

Ogilvie, D., Egan, M., Hamilton, V., \& Petticrew, M. (2004). Promoting walking and cycling as an alternative to using cars: systematic review. BMJ, 329(7469), 763768.

Panter, J. R., Jones, A. P., \& Sluijs, E. M. v. (2008). Environmental determinants of active travel in youth: A review and framework for future research. International Journal of Behavioral Nutrition and Physical Activity, 5, 34-47.

Paul Harland, H. S., Henk A. M. Wilke, (1999). Explaining Proenvironmental Intention and Behavior by Personal Norms and the Theory of Planned Behavior. Journal of Applied Social Psychology, 29(12), 2505-2528.

Paul Harland, H. S., Henk A. M. Wilke, (1999). Explaining Proenvironmental Intention and Behavior by Personal Norms and the Theory of Planned Behavior $<$ sup $>1</$ sup $>$. Journal of Applied Social Psychology, 29(12), 25052528.

Centers for Disease Control and Prevention (2004). Barriers to Children Walking to or from school—United States.

Rossi, P. H. (1980). Why families move (2nd ed.). Beverly Hills, CA: Sage Publications.

Rutherford, G. S., McCormack, E. \& Wilkinson, M. (October,1996). Travel impacts of urban form: Implications from an analysis of two Seattle area travel diaries. Travel Model Improvement Program Conference on Urban Design, Telecommuting and Travel Behavior. University of Washington, Seattle.

Sallis, J. F., \& Owen, N. (1999). Physical activity \& behavioral medicine. Thousand Oaks, CA: Sage Publications.

Schlossberg, M., Greene, J., Phillips, P. P., Johnson, B., \& Parker, B. (2006). School Trips: Effects of Urban From and Distance on Travel Mode. Journal of the American Planning Association, 72(3), 337-346.

Schlossberg, M., Phillips, P. P., Johnson, B., \& Parker, B. (2005). How do they get there? A spatial analysis of a 'sprawl school' in Oregon. Planning Practice \& Research, 20(2), 147-162.

Sebastian Bamberg (2000). The Promotion of New Behavior by Forming an Implementation Intention: Results of a Field Experiment in the Domain of Travel Mode Choice. Journal of Applied Social Psychology, 30(9), 1903-1922.

Schwanen, T.\& Mokhtarian, P. 2004. "The extent and determinants of dissonance between actual and preferred residential neighborhood type," Environment and Planning B: Planning and Design, Pion Ltd, London, vol. 31(5), pages 759-784, September

Schwanen, T.\& Mokhtarian, P. (2007). The Role of Attitudes toward Travel and Land Use in Residential Location Behavior: Some Empirical Evidence from the San Francisco Bay Area. Housing Policy Debate 18(1), 2007, 171-207.

Shwartz, S. (2006). Normative influences on altruism. In L. Berkowitz (Ed.), Advances in experimental social psychology. New York: Academic Press

Sirard, J. R., \& Slater, M. E. (2008). Walking and Bicycling to School: A Review. American Journal of Lifestyle Medicine, 2(5), 372-396. 
Sirard, J. R., \& Slater, M. E. (2008). Walking and Bicycling to School: A Review. American Journal of Lifestyle Medicine, 2(5), 372-396.

Smoyer-Tomic, K. E., Spence, J. C., Raine, K. D., Amrhein, C., Cameron, N., Yasenovskiy, V., et al. (2008). The association between neighborhood socioeconomic status and exposure to supermarkets and fast food outlets. Health \& Place, 14(4), 740-754.

Smyth, A., \& Kelleher, L. (2008). Increasing School Choice: Sustainability Paradox. Paper presented at the Transportation Research Board 87th Annual Meeting.

Staunton, C. E., Hubsmith, D., \& Kallins, W. (2003). Promoting Safe Walking and Biking to School: The Marin County Success Story. Am J Public Health, 93(9), 1431-1434.

Steg, L., Vlek, C., \& Slotegraaf, G. (2001). Instrumental-reasoned and symbolic-affective motives for using a motor car. Transportation Research Part F: Traffic Psychology and Behaviour, 4(3), 151-169.

Steiner, R. Crider, L. \& Betancourt, M. (2006). Safe Ways to school - the role of multimodal planning. Technical report for the Florida Department of Transportation Systems Planning Office (\#BD545).

Stern, P. C. (2000). New Environmental Theories: Toward a Coherent Theory of Environmentally Significant Behavior. Journal of Social Issues, 56, 407-424.

Stradling, S. G., Meadows, M. L., \& Beatty, S. (2000). Helping drivers out of their cars Integrating transport policy and social psychology for sustainable change. Transport Policy, 7(3), 207-215.

Strauss, R. S., \& Pollack, H. A. (2001). Epidemic Increase in Childhood Overweight, 1986-1998. JAMA, 286(22), 2845-2848.

Suminski, R. R., Fritzsinger, J., Leck, T., \& Hyder, M. M. (2008). Observing physical activity in suburbs. Health \& Place, 14(4), 894-899.

Timperio, A., Ball, K., Salmon, J., Roberts, R., Giles-Corti, B., Simmons, D., et al. (2006). Personal, Family, Social, and Environmental Correlates of Active Commuting to School. American Journal of Preventive Medicine, 30(1), 45-51.

Triandis, H. C. (1977). Interpersonal behavior. Monterey, CA: Brooks/Cole.

Ulberg, C. (1989). Psychological aspects of mode choice: Final Report prepared for the Washington State Department (No. WA-RD 189.1). Seattle Washington State Transportation Center

Wall, R., Devine-Wright, P., \& Mill, G. A. (2007). Comparing and Combining Theories to Explain Proenvironmental Intentions: The Case of Commuting-Mode Choice. Environment and Behavior, 39(6), 731-753.

Wen, L. M., Fry, D., Rissel, C., Dirkis, H., Balafas, A., \& Merom, D. (2008). Factors associated with children being driven to school: implications for walk to school programs. Health Education Research, 23(2), 325-334.

Wilson, E. J., Krizek, K. J., Marshall, J., Wilson, R. D., \& Polak, E. (2008). School Choice and Children's School Commuting. Paper presented at the Transportation Research Board 87th Annual Meeting.

Wilson, R. D. (2008). Effect of Education Policy and Urban Form on Elementary-age School Travel. Unpublished Master Thesis, University of Minnesota.

Yang, Y. (2007) "Physical form and neighborhood satisfaction: evidence from the American Housing Survey”. Unpublished dissertation. Cornell University. 
Yarlagadda, A. K. (2008). Modeling children's school travel mode and parental escort decisions. Transportation, 35(2), 201-218.

Yeung, J., Wearing, S., \& Hills, A. P. (2008). Child transport practices and perceived barriers in active commuting to school. Transportation Research Part A: Policy and Practice, 42(6), 895-900.

Yuko Heath, R. G. (2002). Extending the Theory of Planned Behavior: Predicting the Use of Public Transportation. Journal of Applied Social Psychology, 32(10), 2154-2189. 


\section{Appendix A: Survey Instrument}

\section{School Travel Survey}

This survey is being sent to families with elementary students in the Eugene 4J School District. It is a part of a study being undertaken by the University of Oregon Department of Planning, Public Policy, and Management. All information provided in the survey will be kept anonymous. Your response is voluntary and indicates your willingness to participate in this study.

INSTRUCTIONS: This survey should be completed by a parent or guardian. Please answer each question to the best of your ability. All responses will be kept anonymous. Please return your completed survey in the enclosed postage-paid envelope by April 21, 2008. Thank you for your time!

\section{Questions about School and School Travel}

If you have more than ONE child attending an elementary school in the 4J School District, please answer this survey based on the oldest child in elementary school.

1. What type of school does your child attend?

Neighborhood school (your assigned school)

$\square$ Neighborhood school in a neighborhood outside of mine (lottery process)

$\square$ Alternative school (language immersion, etc; lottery process)

2. What is the name of the elementary school your child currently attends?

5. Thinking about this school year (September 2007 - March 2008), how did your child usually travel to elementary school in an average five-day school week? (Please check all that apply.)

NOTE: Throughout this survey the word "bike" is used to refer to any non-motorized transportation with wheels (bike, skateboard, rollerblades, unicycle, etc.)

\begin{tabular}{|c|c|c|c|c|c|c|}
\hline To School & Never & $\begin{array}{l}\text { Once a } \\
\text { week }\end{array}$ & $\begin{array}{l}2 \text { times a } \\
\text { week }\end{array}$ & $\begin{array}{c}3 \text { times a } \\
\text { week }\end{array}$ & $\begin{array}{c}4 \text { times a } \\
\text { week }\end{array}$ & Every day \\
\hline & $\downarrow$ & $\downarrow$ & $\downarrow$ & $\downarrow$ & $\downarrow$ & $\downarrow$ \\
\hline Walked with adult(s) & $\square$ & $\square$ & $\square$ & $\square$ & $\square$ & $\square$ \\
\hline Walked without adult(s) & $\square$ & $\square$ & $\square$ & $\square$ & $\square$ & $\square$ \\
\hline Biked with adult(s) & $\square$ & $\square$ & $\square$ & $\square$ & $\square$ & $\square$ \\
\hline Biked without adult(s) & $\square$ & $\square$ & $\square$ & $\square$ & $\square$ & $\square$ \\
\hline Rode school bus & $\square$ & $\square$ & $\square$ & $\square$ & $\square$ & $\square$ \\
\hline $\begin{array}{l}\text { Rode in a car with a } \\
\text { parent/guardian }\end{array}$ & $\square$ & $\square$ & $\square$ & $\square$ & $\square$ & $\square$ \\
\hline $\begin{array}{l}\text { Rode in a car with an } \\
\text { adult who does not live } \\
\text { in our household } \\
\text { (carpool) }\end{array}$ & $\square$ & $\square$ & $\square$ & $\square$ & $\square$ & $\square$ \\
\hline Other, please specify: & $\square$ & $\square$ & $\square$ & $\square$ & $\square$ & $\square$ \\
\hline
\end{tabular}


6. Thinking about this school year (September 2007 - March 2008), how did your child usually travel from elementary school in an average five-day school week? (Please check all that apply.)

\begin{tabular}{|c|c|c|c|c|c|c|}
\hline From School & Never & $\begin{array}{l}\text { Once a } \\
\text { week }\end{array}$ & $\begin{array}{c}2 \text { times a } \\
\text { week }\end{array}$ & $\begin{array}{c}3 \text { times a } \\
\text { week }\end{array}$ & $\begin{array}{c}4 \text { times a } \\
\text { week }\end{array}$ & Every day \\
\hline & $\downarrow$ & $\downarrow$ & $\downarrow$ & $\downarrow$ & $\downarrow$ & $\downarrow$ \\
\hline Walked with adult(s) & $\square$ & $\square$ & $\square$ & $\square$ & $\square$ & $\square$ \\
\hline Walked without adult(s) & $\square$ & $\square$ & $\square$ & $\square$ & $\square$ & $\square$ \\
\hline Biked with adult(s) & $\square$ & $\square$ & $\square$ & $\square$ & $\square$ & $\square$ \\
\hline Biked without adult(s) & $\square$ & $\square$ & $\square$ & $\square$ & $\square$ & $\square$ \\
\hline Rode school bus & $\square$ & $\square$ & $\square$ & $\square$ & $\square$ & $\square$ \\
\hline $\begin{array}{l}\text { Rode in a car with a } \\
\text { parent/guardian }\end{array}$ & $\square$ & $\square$ & $\square$ & $\square$ & $\square$ & $\square$ \\
\hline $\begin{array}{l}\text { Rode in a car with an } \\
\text { adult who does not live } \\
\text { in our household } \\
\text { (carpool) }\end{array}$ & $\square$ & $\square$ & $\square$ & $\square$ & $\square$ & $\square$ \\
\hline Other, please specify: & $\square$ & $\square$ & $\square$ & $\square$ & $\square$ & $\square$ \\
\hline
\end{tabular}

\section{Questions about School Choice and Housing Choice}

7. How long have you lived in this area (i.e., Lane County)? years

\section{How long have you lived in your current} residence? years

9. Do you own or rent the place where you live?

$\square$ Own

$\square$ Rent

$\square$ Other (specify)

10. Were you aware of the 4J School Choice policy when you chose your current residence?
$\square$ Yes
$\square$ No

11. When choosing your current residence, did you first decide where you wanted your child(ren) to go to school, THEN find a place to live in the school attendance area?

$\square$ Yes $\quad \square$ No

$\square$ I did not have children when I was looking for a place to live.

$\square$ I knew that I would use school choice.
12. Did having the option of school choice influence your decision about where to live?
$\square$ Yes
$\square$ No

$\square$ I was not aware of school choice when I moved into my current residence.

13. If your child could only attend the school in your neighborhood, would you still have chosen the residence you live in?
$\square$ Yes
$\square$ No

14. Regardless of how your child currently travels to school, what type of school transportation did you have in mind when you chose your current residence?

$\square$ Bus $\square$ Car $\square$ Walking $\square$ Biking

$\square$ I didn't think about it $\square$ other

15. How far do you live from the school your child currently attends?

Approximately miles, or minutes driving a car

16. Do you consider this a walkable or bikeable distance for your child at this time?

A walkable distance to the school: YES NO A bikeable distance to the school: YES NO 
17. Please tell us how important the following characteristics were when you chose the location of your current residence. (Please circle the number that best applies.)

\begin{tabular}{|c|c|c|c|c|c|}
\hline & $\begin{array}{c}\text { Not } \\
\text { Important }\end{array}$ & $\begin{array}{l}\text { Somewhat } \\
\text { Important }\end{array}$ & Important & $\begin{array}{c}\text { Very } \\
\text { Important }\end{array}$ & $\begin{array}{l}\text { Extremely } \\
\text { Important }\end{array}$ \\
\hline \multicolumn{6}{|l|}{ Residence } \\
\hline $\begin{array}{l}\text { 1. Characteristics of residence itself (size, } \\
\text { number of rooms, aesthetics) }\end{array}$ & 1 & 2 & 3 & 4 & 5 \\
\hline 2. Cost of housing & 1 & 2 & 3 & 4 & 5 \\
\hline 3. Size of lot/yard & 1 & 2 & 3 & 4 & 5 \\
\hline 4. View from residence & 1 & 2 & 3 & 4 & 5 \\
\hline \multicolumn{6}{|l|}{ Neighborhood } \\
\hline 5. Reputation of neighborhood & 1 & 2 & 3 & 4 & 5 \\
\hline $\begin{array}{l}\text { 6. Friends and/or relatives live in the } \\
\text { neighborhood }\end{array}$ & 1 & 2 & 3 & 4 & 5 \\
\hline 7. Ease of walking/biking & 1 & 2 & 3 & 4 & 5 \\
\hline 8. Sense of community & 1 & 2 & 3 & 4 & 5 \\
\hline 9. Safety for my children & 1 & 2 & 3 & 4 & 5 \\
\hline 10. Pedestrian and biking safety & 1 & 2 & 3 & 4 & 5 \\
\hline 11. Safety from crime & 1 & 2 & 3 & 4 & 5 \\
\hline 12. The design or look of the neighborhood & 1 & 2 & 3 & 4 & 5 \\
\hline \multicolumn{6}{|l|}{ Access } \\
\hline 13. Proximity to neighborhood school & 1 & 2 & 3 & 4 & 5 \\
\hline 14. Proximity to place of work & 1 & 2 & 3 & 4 & 5 \\
\hline 15. Proximity to stores & 1 & 2 & 3 & 4 & 5 \\
\hline 16. Proximity to public transportation & 1 & 2 & 3 & 4 & 5 \\
\hline 17. Proximity to open space, such as parks & 1 & 2 & 3 & 4 & 5 \\
\hline $\begin{array}{l}\text { 18. Proximity to recreational facilities, such } \\
\text { as pools, gyms, athletic fields, etc. }\end{array}$ & 1 & 2 & 3 & 4 & 5 \\
\hline 19. Proximity to freeways & 1 & 2 & 3 & 4 & 5 \\
\hline \multicolumn{6}{|l|}{ School } \\
\hline 20. Quality of neighborhood school & 1 & 2 & 3 & 4 & 5 \\
\hline $\begin{array}{l}\text { 21. Ability for my child to walk/bike to } \\
\text { school }\end{array}$ & 1 & 2 & 3 & 4 & 5 \\
\hline 22. Availability of school bus & 1 & 2 & 3 & 4 & 5 \\
\hline \multicolumn{6}{|l|}{ Other reason (please specify) } \\
\hline 23. & 1 & 2 & 3 & 4 & 5 \\
\hline 24. & 1 & 2 & 3 & 4 & 5 \\
\hline
\end{tabular}

17A. Please write the numbers of the 3 most important reasons from above:

Most important:

Second most important:

Third most important: 
18. We are interested in why families make certain types of school travel decisions. If your child walks or bikes to school LESS than three days per week, please answer Questions 18A \& B. If your child walks or bikes to school Tthree days or MORE per week, skip Questions $18 \mathrm{~A} \& \mathrm{~B}$ and answer $18 \mathrm{C}$ \& D.

18A. Below is a list of reasons that might factor into your school travel choices. Please circle how important each reason was when making your decision to use the car or school bus rather than walking or biking.

\begin{tabular}{|c|c|c|c|c|c|c|}
\hline & $\begin{array}{c}\text { Not } \\
\text { Important }\end{array}$ & $\begin{array}{l}\text { Somewhat } \\
\text { Important }\end{array}$ & Important & $\begin{array}{c}\text { Very } \\
\text { Important }\end{array}$ & $\begin{array}{l}\text { Extremely } \\
\text { Important }\end{array}$ & N/A \\
\hline $\begin{array}{l}\text { 1. Distance from residence to school too } \\
\text { far }\end{array}$ & 1 & 2 & 3 & 4 & 5 & $\square$ \\
\hline $\begin{array}{l}\text { 2. Child is too young - not ready to walk } \\
\text { or bike to school }\end{array}$ & 1 & 2 & 3 & 4 & 5 & $\square$ \\
\hline $\begin{array}{l}\text { 3. Not enough time in the morning or } \\
\text { afternoon to walk or bike }\end{array}$ & 1 & 2 & 3 & 4 & 5 & $\square$ \\
\hline $\begin{array}{l}\text { 4. Child has too much to carry (e.g., } \\
\text { heavy backpack) }\end{array}$ & 1 & 2 & 3 & 4 & 5 & $\square$ \\
\hline 5. Bad weather & 1 & 2 & 3 & 4 & 5 & $\square$ \\
\hline $\begin{array}{l}\text { 6. No one is available to accompany my } \\
\text { child to walk or bike to school }\end{array}$ & 1 & 2 & 3 & 4 & 5 & $\square$ \\
\hline 7. Fear of child getting hurt or abducted & 1 & 2 & 3 & 4 & 5 & $\square$ \\
\hline $\begin{array}{l}\text { 8. Concern with traffic (e.g., lots of } \\
\text { traffic on roads and/or roads crossing) }\end{array}$ & 1 & 2 & 3 & 4 & 5 & $\square$ \\
\hline $\begin{array}{l}\text { 9. Obstacles along the route (e.g., hills, } \\
\text { railroad crossings) }\end{array}$ & 1 & 2 & 3 & 4 & 5 & $\square$ \\
\hline $\begin{array}{l}\text { 10. No or inadequate place to walk or } \\
\text { bike (e.g., lack of sidewalks or bike } \\
\text { lanes) }\end{array}$ & 1 & 2 & 3 & 4 & 5 & $\square$ \\
\hline $\begin{array}{l}\text { 11. Lack of safe bike parking at the } \\
\text { school }\end{array}$ & 1 & 2 & 3 & 4 & 5 & $\square$ \\
\hline $\begin{array}{l}\text { 12. Car travel allows child to get more } \\
\text { sleep in the morning }\end{array}$ & 1 & 2 & 3 & 4 & 5 & $\square$ \\
\hline $\begin{array}{l}\text { 13. Faster speed (less time) allowed by } \\
\text { car travel }\end{array}$ & 1 & 2 & 3 & 4 & 5 & $\square$ \\
\hline $\begin{array}{l}\text { 14. Combining school trip with other } \\
\text { trips (e.g., trip to workplace, shopping) }\end{array}$ & 1 & 2 & 3 & 4 & 5 & $\square$ \\
\hline $\begin{array}{l}\text { 15. Need to transport more than one } \\
\text { child to different schools }\end{array}$ & 1 & 2 & 3 & 4 & 5 & $\square$ \\
\hline 16. Quality time spent with child in car & 1 & 2 & 3 & 4 & 5 & $\square$ \\
\hline $\begin{array}{l}\text { Other reasons (please specify) } \\
17 .\end{array}$ & 1 & 2 & 3 & 4 & 5 & $\square$ \\
\hline 18. & 1 & 2 & 3 & 4 & 5 & $\square$ \\
\hline
\end{tabular}

18B. Please write the numbers of the 3 most important reasons from above:

Most important: Second most important: Third most important: 
18C. Below is a list of reasons that might factor into your school travel choices. Please check how important each reason was when making your decision to let your child walk or ride a bike to/from school instead of driving or using the school bus.

\begin{tabular}{|c|c|c|c|c|c|c|}
\hline & $\begin{array}{c}\text { Not } \\
\text { Important }\end{array}$ & $\begin{array}{l}\text { Somewhat } \\
\text { Important }\end{array}$ & Important & $\begin{array}{c}\text { Very } \\
\text { Important }\end{array}$ & $\begin{array}{l}\text { Extremely } \\
\text { Important }\end{array}$ & N/A \\
\hline $\begin{array}{l}\text { 1. Combining school trip with other trips } \\
\text { (e.g., walk or bike to workplace) }\end{array}$ & 1 & 2 & 3 & 4 & 5 & $\square$ \\
\hline 2. Increase child's physical activity & 1 & 2 & 3 & 4 & 5 & $\square$ \\
\hline $\begin{array}{l}\text { 3. Quality time spent with child together } \\
\text { walking or biking to school }\end{array}$ & 1 & 2 & 3 & 4 & 5 & $\square$ \\
\hline 4. No car available & 1 & 2 & 3 & 4 & 5 & $\square$ \\
\hline 5. Save money & 1 & 2 & 3 & 4 & 5 & $\square$ \\
\hline 6. Faster than driving a car & 1 & 2 & 3 & 4 & 5 & $\square$ \\
\hline 7. No place to park car around school & 1 & 2 & 3 & 4 & 5 & $\square$ \\
\hline 8. Avoid car traffic around school & 1 & 2 & 3 & 4 & 5 & $\square$ \\
\hline 9. No school bus available & 1 & 2 & 3 & 4 & 5 & $\square$ \\
\hline \multicolumn{7}{|l|}{ Other (please specify) } \\
\hline 10. & 1 & 2 & 3 & 4 & 5 & $\square$ \\
\hline 11. & 1 & 2 & 3 & 4 & 5 & $\square$ \\
\hline 12. & 1 & 2 & 3 & 4 & 5 & $\square$ \\
\hline 13. & 1 & 2 & 3 & 4 & 5 & $\square$ \\
\hline
\end{tabular}

18D. Please write the numbers of the 3 most important reasons from above:

Most important: Second most important: Third most important:

19. On a scale of 1 to 5 , express your level of agreement (or disagreement) with the following statements. $\mathbf{1}=$ strongly disagree.... $\mathbf{5}=$ strongly agree [Circle a number for each statement.]

1. For trips around town, driving is a more comfortable way of travel than walking or biking.

$\begin{array}{ccccc}1 & 2 & \begin{array}{c}3 \\ \text { neutral }\end{array} & 4 & \begin{array}{c}5 \\ \text { strongly agree }\end{array}\end{array}$

2. I generally prefer driving whenever I need to go places in this area.

$\begin{array}{ccccc}1 & 2 & 3 & 4 & 5 \\ \text { strongly disagree } & & \text { neutral } & & \\ \text { strongly agree }\end{array}$

3. Parents driving children to schools, particularly in the morning, has contributed to the rush hour congestion.
$\stackrel{1}{\text { strongly disagree }}$
3
neutral
5
strongly agree

4.Walking or biking, whenever possible, is a way to demonstrate one's commitment to protecting the environment.

$\begin{array}{ccccc}1 & 2 & 3 & 4 & 5 \\ \text { strongly disagree } & & \text { neutral } & & \text { strongly agree }\end{array}$

5. Children walking or biking to school is a good way to increase their physical activity.

$\begin{array}{ccccc}1 & 2 & 3 & 4 & 5 \\ \text { strongly disagree } & & \text { neutral } & & \text { strongly agree }\end{array}$

6. It is easy to find good housing in Eugene where I do not need to rely on a car for everything.
1
2
3
neutral
45
5
sungly agree 
19. Continued. On a scale of 1 to 5, express your level of agreement (or disagreement) with the following statements. $1=$ strongly disagree.... $5=$ strongly agree [Circle a number for each statement.]

7. To me, owning a car is a status symbol.

\begin{tabular}{|c|c|}
\hline $\begin{array}{l}1 \\
\text { strongly dikagree }\end{array}$ & 2 \\
\hline
\end{tabular}

8. Traffic and congestion in this area do not bother me.

\begin{tabular}{|c|c|}
\hline $\begin{array}{c}1 \\
\text { strongly disagree }\end{array}$ & 2 \\
\hline
\end{tabular}

9. It is easy to find good housing close to the school where I want my child to go.

\begin{tabular}{|c|c|}
\hline 1 & 2 \\
\hline
\end{tabular}

10. Owning a car contributes to a comfortable lifestyle.

\begin{tabular}{|c|c|}
\hline $\begin{array}{c}1 \\
\text { strongly disagree }\end{array}$ & 2 \\
\hline
\end{tabular}

11. Children who are always transported by adults to do things may develop a habit of relying on an automobile in their later life.

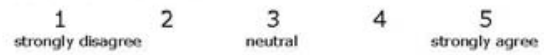

12. If possible, I would like for my child to walk and/or bike to school.

\begin{tabular}{|c|c|}
\hline$\stackrel{1}{1}$ & 2 \\
\hline
\end{tabular}

13. Schools should provide more parking spaces for parents who drive their children.

$\begin{array}{lccc}1 & 2 & 3 & 5 \\ \text { strongly disagree } & 5 & 5 \\ \text { neutral } & & \end{array}$

14. Children should all go to their own neighborhood schools.

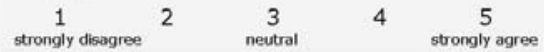
help them know their neighborhood.

$\begin{array}{ccccc}1 & 2 & 3 & 4 & 5 \\ \text { strongly disagree } & & \text { neutral } & & \begin{array}{c}5 \\ \text { strongly agree }\end{array}\end{array}$

16. Driving to school contributes to environmenta pollution.

$\begin{array}{ccccc}1 & 2 & 3 & 4 & 5 \\ \text { strongly disagree } & & \text { neutral } & & \text { strongly agree }\end{array}$

17. I have to drive around to do things - even if I would rather not.

$\begin{array}{ccccc}1 & 2 & 3 & 4 & 5 \\ \text { strongly disagree } & & \text { neutral } & & \text { strongly agree }\end{array}$

18. I feel like I drive my car as much as other people do.

$\begin{array}{ccccc}1 & 2 & 3 & 4 & 5 \\ \text { strongly disagree } & & \text { neutral } & & 5 \text { strongly agree }\end{array}$

19. As an individual, I can make a difference when it comes to conserving energy and protecting the environment.

$\begin{array}{ccccc}1 & 2 & 3 & 4 & 5 \\ \text { strongly disagree } & & \text { neutral } & & 5 \\ \text { strongly agree }\end{array}$

20. I believe that the layout of my neighborhood makes it a good place for walking.

$\begin{array}{ccccc}1 & 2 & 3 & 4 & 5 \\ \text { strongly disagree } & & \text { neutral } & & \\ \text { strongly agree }\end{array}$

21. Eugene should develop in a way that makes people less dependent on automobiles.

$\begin{array}{ccccc}1 & 2 & 3 & 4 & 5 \\ \text { strongly disagree } & & \text { neutral } & & \text { strongly agree }\end{array}$

gets there safely.

\begin{tabular}{ccccc}
1 & 2 & 3 & 4 & 5 \\
strongly disagree & neutral & & $\begin{array}{c}5 \\
\text { strongly agree }\end{array}$ \\
\hline
\end{tabular}

20. In your opinion, what is the appropriate age for a child to walk or bike to school (elementary, middle, or high school), regardless of the type of transportation your child is currently using?

$\square$ with adult accompanying

$\square$ without adult accompanying

$\square$ Never

21. Do you plan to change your child's school transportation in the future before he or she goes on to middle school?

$\square$ Yes $\square$ No

If yes, please specify: 


\section{Questions about You and Your Household}

All information provided in the survey will be kept anonymous.

22. How many adults ( 18 years + ) live in your household?

23. How many children live in your household?

24. How many cars does your household own?
25. Is English the primary language spoken at home?

$$
\square \text { Yes } \square \text { No }
$$

26. What is your gender?

$$
\square \text { Female } \square \text { Male }
$$

27. Please estimate your 2007 total household income before taxes:
Under $\$ 10,000$
ㅁ $\$ 30,000$ to $\$ 34,999$
$\square \$ 60,000$ to $\$ 74,999$
$\$ 10,000$ to $\$ 14,999$
$\$ 35,000$ to $\$ 39,999$
$\square \$ 75,000$ to $\$ 99,999$
$\square \$ 15,000$ to $\$ 19,999$
$\square \$ 40,000$ to $\$ 44,999$
ㅁ $\$ 100,000$ or more
ㅁ $\$ 20,000$ to $\$ 24,999$
ㅁ $\$ 45,000$ to $\$ 49,999$
ㅁ $\$ 25,000$ to $\$ 29,999$
ㅁ $\$ 50,000$ to $\$ 59,999$

28. Please tell us the employment status for all adults in your household, and the place of work for

\begin{tabular}{|c|c|c|c|c|c|c|c|c|}
\hline \multirow[b]{3}{*}{ Adult 1} & \multicolumn{5}{|c|}{ Employment status } & \multicolumn{3}{|c|}{ Place of work } \\
\hline & $\begin{array}{l}\text { Full- } \\
\text { time }\end{array}$ & $\begin{array}{l}\text { Part- } \\
\text { time }\end{array}$ & $\begin{array}{c}\text { Full- } \\
\text { time } \\
\text { student }\end{array}$ & $\begin{array}{l}\text { Part- } \\
\text { time } \\
\text { student }\end{array}$ & $\begin{array}{c}\text { Not } \\
\text { Employed }\end{array}$ & $\begin{array}{c}\text { Always at } \\
\text { home }\end{array}$ & $\begin{array}{l}\text { At home and } \\
\text { outside of } \\
\text { home }\end{array}$ & $\begin{array}{l}\text { Always } \\
\text { outside of } \\
\text { home }\end{array}$ \\
\hline & $\square$ & $\square$ & $\square$ & $\square$ & $\square$ & $\square$ & $\square$ & $\square$ \\
\hline Adult 2 & $\square$ & $\square$ & $\square$ & $\square$ & $\square$ & $\square$ & $\square$ & $\square$ \\
\hline Adult 3 & $\square$ & $\square$ & $\square$ & $\square$ & $\square$ & $\square$ & $\square$ & $\square$ \\
\hline Adult 4 & $\square$ & $\square$ & $\square$ & $\square$ & $\square$ & $\square$ & $\square$ & $\square$ \\
\hline Adult 5 & $\square$ & $\square$ & $\square$ & $\square$ & $\square$ & $\square$ & $\square$ & $\square$ \\
\hline
\end{tabular}
those who are employed. (Please answer for persons older than 18, check all that apply.)

29. Please tell us the highest education level for all adults in your household. (Please answer for persons older than 18.)

\begin{tabular}{|c|cccccc|}
\hline & $\begin{array}{c}\text { Did not } \\
\text { complete } \\
\text { high school }\end{array}$ & $\begin{array}{c}\text { High School } \\
\text { graduate/GED }\end{array}$ & $\begin{array}{c}\text { Some } \\
\text { College/ } \\
\text { Associate }\end{array}$ & $\begin{array}{c}\text { College } \\
\text { degree }\end{array}$ & $\begin{array}{c}\text { Post graduate } \\
\text { (Master, } \\
\text { professional, } \\
\text { Dr.) }\end{array}$ & $\begin{array}{c}\text { Don't } \\
\text { know }\end{array}$ \\
Adult 1 & $\square$ & $\square$ & $\square$ & $\square$ & $\square$ & $\square$ \\
Adult 2 & $\square$ & $\square$ & $\square$ & $\square$ & $\square$ & $\square$ \\
Adult 3 & $\square$ & $\square$ & $\square$ & $\square$ & $\square$ & $\square$ \\
Adult 4 & $\square$ & $\square$ & $\square$ & $\square$ & $\square$ \\
Adult 5 & $\square$ & $\square$ & $\square$ & $\square$ & $\square$ \\
\hline
\end{tabular}


30. Please tell us the ethnic or racial identity for the adult members in the household. (Please answer for persons older than 18.)

\begin{tabular}{|c|ccccccc|}
\hline \multicolumn{1}{|c}{} & $\begin{array}{c}\text { American } \\
\text { Indian or } \\
\text { Alaska } \\
\text { Native }\end{array}$ & $\begin{array}{c}\text { Native } \\
\text { Hawaiian or } \\
\text { Other Pacific } \\
\text { Islander }\end{array}$ & Asian & $\begin{array}{c}\text { Black or } \\
\text { African } \\
\text { American }\end{array}$ & $\begin{array}{c}\text { Latino/ } \\
\text { Hispanic }\end{array}$ & $\begin{array}{c}\text { White/ } \\
\text { Caucasian } \\
\text { (Non- } \\
\text { Hispanic) }\end{array}$ & other \\
\cline { 2 - 9 } Adult 1 & $\square$ & $\square$ & $\square$ & $\square$ & $\square$ & $\square$ & $\square$ \\
Adult 2 & $\square$ & $\square$ & $\square$ & $\square$ & $\square$ & $\square$ & $\square$ \\
Adult 3 & $\square$ & $\square$ & $\square$ & $\square$ & $\square$ & $\square$ & $\square$ \\
Adult 4 & $\square$ & $\square$ & $\square$ & $\square$ & $\square$ & $\square$ & $\square$ \\
Adult 5 & $\square$ & $\square$ & $\square$ & $\square$ & $\square$ & $\square$ & $\square$ \\
\hline
\end{tabular}

Please use the space provided here for your comments about issues related to school travel and housing opportunities in this area. Thank You! 


\section{Appendix B: Survey Questions for Measuring Important Variables}

\begin{tabular}{|c|c|c|}
\hline $\begin{array}{l}\text { Major concepts/ } \\
\text { measures }\end{array}$ & Statements or Questions (Answers) & $\begin{array}{l}\text { Variable values used in } \\
\text { analysis }\end{array}$ \\
\hline $\begin{array}{l}\text { Attitude toward } \\
\text { child walking or } \\
\text { biking to school } \\
\text { (individual belief } \\
\text { statement and } \\
\text { factor) }\end{array}$ & $\begin{array}{l}\text { - Children who are always transported by adults to do things may develop a habit of relying on an } \\
\text { automobile in their later life. (strongly disagree, disagree, neutral, agree, strongly agree) } \\
\text { - Children walking or biking to school is a good way to help them know their neighborhood. (strongly } \\
\text { disagree, disagree, neutral, agree, strongly agree) } \\
\text { - Children walking or biking to school is a good way to increase their physical activity. (strongly disagree, } \\
\text { disagree, neutral, agree, strongly agree) } \\
\text { - Parents driving children to schools, particularly in the morning, has contributed to the rush hour } \\
\text { congestion. (strongly disagree, disagree, neutral, agree, strongly agree) } \\
\text { - Driving to school contributes to environmental pollution. (strongly disagree, disagree, neutral, agree, } \\
\text { strongly agree) }\end{array}$ & $\begin{array}{l}1 \text { to } 5 \\
1 \text { to } 5 \\
1 \text { to } 5 \\
1 \text { to } 5 \\
1 \text { to } 5\end{array}$ \\
\hline $\begin{array}{l}\text { Attitude toward } \\
\text { car use } \\
\text { (individual belief } \\
\text { statement and } \\
\text { factor) }\end{array}$ & $\begin{array}{l}\text { - For trips around town, driving is a more comfortable way of travel than walking or biking. (strongly } \\
\text { disagree, disagree, neutral, agree, strongly agree) } \\
\text { - I generally prefer driving whenever I need to go places in this area. (strongly disagree, disagree, neutral, } \\
\text { agree, strongly agree) } \\
\text { - To me, owning a car is a status symbol. (strongly disagree, disagree, neutral, agree, strongly agree) } \\
\text { - Owning a car contributes to a comfortable lifestyle. (strongly disagree, disagree, neutral, agree, strongly } \\
\text { agree) } \\
\text { - I feel like I drive my car as much as other people do. (strongly disagree, disagree, neutral, agree, strongly } \\
\text { agree) }\end{array}$ & $\begin{array}{l}1 \text { to } 5 \\
1 \text { to } 5 \\
1 \text { to } 5 \\
1 \text { to } 5 \\
1 \text { to } 5\end{array}$ \\
\hline $\begin{array}{l}\text { Preference for } \\
\text { ASC }\end{array}$ & $\begin{array}{l}\text { If possible, I would like for my child to walk and/or bike to school. (strongly disagree, disagree, neutral, } \\
\text { agree, strongly agree) }\end{array}$ & 1 to 5 \\
\hline $\begin{array}{l}\text { Intention or } \\
\text { consideration of } \\
\text { using ASC }\end{array}$ & $\begin{array}{l}\text { What transportation means did you have in mind when chose your current residence, regardless of what } \\
\text { you are using now? }\end{array}$ & 1 or 0 (using ASC) \\
\hline $\begin{array}{l}\text { Environmental } \\
\text { conditions }\end{array}$ & $\begin{array}{l}\text { - Distance between residence and school (miles). Do you consider this a walkable or bikeable distance for } \\
\text { your child at this time? (yes or no) } \\
\text { - Neighborhood walkability: I believe that the layout of my neighborhood makes it a good place for } \\
\text { walking. (strongly disagree, disagree, neutral, agree, strongly agree) } \\
\text { - Safety concerns: Only driving my child to school ensures safe arrival (strongly disagree, disagree, }\end{array}$ & 1 or 0 \\
\hline
\end{tabular}




\begin{tabular}{|l|l|l|}
\hline & $\begin{array}{l}\text { neutral, agree, strongly agree) } \\
\text { - School environment (location): \% of residential land around a quarter mile of school, total length of } \\
\text { streets around school, density around school }\end{array}$ & Continuous (GIS-based) \\
\hline Other control var & $\begin{array}{l}\text { - Family (income, education, race/ethnicity, number of cars owned, employment status of adults) } \\
\text { Child's age } \\
\text { - School type }\end{array}$ & $\begin{array}{l}\text { Dummy vars } \\
\text { Numerical } \\
\text { Dummy vars }\end{array}$ \\
\hline
\end{tabular}




\section{Appendix C: Descriptive Statistics for Major Variables}

$\mathbf{N}$

Mean

Std. error

ive school commuting (walking or biking to school)

$>=3$ days per week

$1195 \quad 0.146 \quad 0.010$

¿ preferece (value $=1 \sim 5)$

$1185 \quad 3.988 \quad 0.033$

rironmental variables

home-school distance (mi)

$1197 \quad 1.770 \quad 0.062$

neighborhood walkability (1 5)

$1197 \quad 3.555 \quad 0.040$

Safety concerns $(1 \sim 5)$

$1175 \quad 2.922 \quad 0.045$

ool variables

attending own neighborhood school

$1188 \quad 0.546 \quad 0.014$

Total street length w/in quarter-mi of school (1000 feet) $\quad \begin{array}{lll}1104 & 1500 & 0.209\end{array}$

$\begin{array}{llll}\text { Percentage of residential land w/in quarter-mi of school } & 1104 & 0.630 & 0.010\end{array}$

Average lot size w/in quarter-mi of school

$1104 \quad 0.240 \quad 0.002$

ısehold variables

income

$1147 \quad 75455 \quad 1415$

highest eduation is bachelor or above

$1171 \quad 0.720 \quad 0.013$

race/ethnicity (1=white)

$\begin{array}{lll}1175 & 0.795 & 0.012\end{array}$

number of cars owned

$1197 \quad 1.931 \quad 0.028$

at least one adult is not employed

$\begin{array}{lll}1182 & 0.285 & 0.013\end{array}$

parnet(s) fulltime employed

$1182 \quad 0.302 \quad 0.013$

child's age

\begin{tabular}{lll}
1197 & $7.910 \quad 0.048$ \\
\hline
\end{tabular}






\section{AOTREC \\ OREGON TRANSPORTATION RESEARCH \\ AND EDUCATION CONSORTIUM}

\section{P.O. Box 751}

Portland, OR 97207

OTREC is dedicated to stimulating and conducting collaborative multi-disciplinary research on multi-modal surface transportation issues, educating a diverse array of current practitioners and future leaders in the transportation field, and encouraging implementation of relevant research results. 